\title{
Identification of the Aerosol Types over Athens, Greece: The Influence of Air-Mass Transport
}

\author{
D. G. Kaskaoutis, ${ }^{1}$ P. G. Kosmopoulos, ${ }^{2}$ H. D. Kambezidis, ${ }^{1}$ and P. T. Nastos ${ }^{2}$ \\ ${ }^{1}$ Atmospheric Research Team, Institute for Environmental Research and Sustainable Development, National Observatory of Athens, \\ Lofos Nymphon, P.O. Box 20048, 11810 Athens, Greece \\ ${ }^{2}$ Department of Geology and Geo-Environment, University of Athens, University Campus, 15784 Zografou, Greece
}

Correspondence should be addressed to H. D. Kambezidis, harry@meteo.noa.gr

Received 27 June 2009; Revised 4 September 2009; Accepted 3 October 2009

Academic Editor: Krishnaswamy Krishnamoorthy

Copyright ( $) 2010$ D. G. Kaskaoutis et al. This is an open access article distributed under the Creative Commons Attribution License, which permits unrestricted use, distribution, and reproduction in any medium, provided the original work is properly cited.

Aerosol optical depth at $550 \mathrm{~nm}\left(\mathrm{AOD}_{550}\right)$ and fine-mode $(\mathrm{FM})$ fraction data from Terra-MODIS were obtained over the Greater Athens Area covering the period February 2000-December 2005. Based on both $\mathrm{AOD}_{550}$ and FM values three main aerosol types have been discriminated corresponding to urban/industrial aerosols, clean maritime conditions, and coarse-mode, probably desert dust, particles. Five main sectors were identified for the classification of the air-mass trajectories, which were further used in the analysis of the $\left(\mathrm{AOD}_{550}\right.$ and FM data for the three aerosol types). The HYSPLIT model was used to compute back trajectories at three altitudes to investigate the relation between $\mathrm{AOD}_{550}-\mathrm{FM}$ and wind sector depending on the altitude. The accumulation of local pollution is favored in spring and corresponds to air masses at lower altitudes originating from Eastern Europe and the Balkan. Clean maritime conditions are rare over Athens, limited in the winter season and associated with air masses from the Western or Northwestern sector. The coarse-mode particles origin seems to be more complicated proportionally to the season. Thus, in summer the Northern sector dominates, while in the other seasons, and especially in spring, the air masses belong to the Southern sector enriched with Saharan dust aerosols.

\section{Introduction}

Atmospheric aerosols play a crucial role in the Earth's climate through scattering and absorption both solar and thermal radiation (direct effect), thus influencing the radiative and energy balance and/or acting as cloud condensation nuclei (indirect effect), affecting cloud albedo and lifetime, precipitation rate, and hydrology cycle [1]. The great effort spent over the last decades by the scientific community focusing on aerosol climatology and optical properties reflects the importance attributed to aerosols in controlling the Earth's climate [2]. Major advancements in this field have been achieved by the new generation of space borne instruments (e.g., Along Track Scanning Radiometer (ATSR-2) on board the European Space Agency (ESA-ERS2), Moderate Resolution Imaging Spectroradiometer (MODIS), and Multiangle Imaging Spectroradiometer (MISR) on board the NASA Terra, POLarization and Directionality of the Earth's Reflectances (POLDER) on board the ADEOS), specifically designed to provide detection and characterization of atmospheric aerosols [3].

The Mediterranean Sea is one of the most affected areas regarding aerosol load in the world [4]. Due to the variety of the regions surrounding the Mediterranean basin, different aerosol types can be found within the basin, having both strong temporal and spatial distribution $[4,5]$; desert dust, originated from the Sahara desert, polluted aerosols produced mainly in urban and industrial centers of Continental and Eastern Europe, marine aerosols, formed over Mediterranean itself or transported from the North Atlantic, and biomass smoke often produced by seasonal forest fires.

Transport of Saharan dust from the North African arid regions towards Mediterranean and coastal Europe has been widely investigated, either in the form of statistical analyses or as "case studies" using ground-based instrumentation, sun photometers, lidar and satellite observations [6-10]. In contrast, studies for the particle transport from the 
European continent to the Mediterranean Sea are still limited. However, a growing scientific interest in this topic is now developed, and in this way an international effort to quantify the impact of anthropogenic emissions on the Eastern Mediterranean is represented by the Mediterranean Intensive Oxidant Study (MINOS) campaign. That campaign highlighted the important role of pollutants in the Mediterranean atmosphere during summer [11]. Pollution transfer models have also been successfully utilized to investigate the export pathways of air pollution from Europe $[12,13]$. Nevertheless, the investigation of the export of pollutants from the industrialized areas surrounding the Eastern Mediterranean and Aegean Sea is not an easy task due to the fact that a large number of aerosols and gas precursors (including organic and inorganic compounds) contribute to it. Model calculations also indicate that pollutants emitted from Central and Eastern Europe are transported towards the Eastern Mediterranean [14], and hence, anthropogenic aerosols and their direct radiative effects are considered to be significant. In addition to long-range transport, this region is affected from pollution caused by local metropolitan areas, such as Athens. The identification of clean marine conditions over Eastern Mediterranean is particularly rare, due to the influence of continental aerosols (natural and anthropogenic). Prospero et al. [15] investigated aerosols over different oceanic areas and reported that the Mediterranean ones were heavily contaminated by dust and anthropogenic pollutants. Moreover, Heintzenberg et al. [16] excluded Mediterranean and other closed seas (Baltic, Yellow Sea) as not representative for the investigation of chemical composition of marine aerosols.

The MODIS products of aerosol optical depth at $(550 \mathrm{~nm})\left(\mathrm{AOD}_{550}\right)$ and fine-mode $(\mathrm{FM})$ fraction were obtained over Athens covering the period February 2000December 2005. These observations, in combination with the air-mass trajectories, aim to identify the aerosol types originating from different sectors and determine their seasonal optical properties. A recent work by Kaskaoutis et al. [17] investigated the optical properties of specific aerosol types over Athens, while Kosmopoulos et al. [18] analyzed the seasonal variation of three different aerosol types; both studies used the same data set. The main contribution of the present study, though, is the investigation of the prime pathways favoring the presence of specific aerosol types over Athens. Such a long-term ( $\sim 6$ years) analysis associating the aerosol types and properties with air-mass trajectories constitutes the first study conducted over Athens. It is also highlighted that different aerosol types can occur simultaneously in the atmosphere transported by air masses of different origins. In addition, the major role of the vertical transport is underlined favoring the domination of different aerosol types in relation to the season and the synoptic meteorological patterns.

\section{Data Collection}

2.1. MODIS Retrievals. The Moderate Resolution Imaging Spectroradiometer (MODIS) was launched in December
1999 on the polar orbiting NASA-EOS Terra spacecraft with a dayside equatorial 10:30 AM local crossing time. Aerosol retrievals from MODIS data are performed over land and ocean surfaces by means of two separate algorithms thoroughly described in Kaufman and Tanré [19]. The two aerosol products employed in this study are (1) the optical thickness at $550 \mathrm{~nm}\left(\mathrm{AOD}_{550}\right)$ and (2) the fine-mode fraction (FM). The latter is derived as the ratio of optical depth of small mode versus effective optical depth at $550 \mathrm{~nm}$. The MODIS aerosol products are only created for cloudfree regions, although Levy et al. [20] showed that MODIS can retrieve optical properties even in case that a $10 \times$ $10 \mathrm{~km}$ pixel (Level 2) is about $90 \%$ cloudy. Both $\mathrm{AOD}_{550}$ and FM data used in the present study were retrieved by MODIS and correspond to Collection 5 (C005) data. The FM fraction was initially given over ocean. Nevertheless, Chu et al. [21] showed that the separation of fine- and coarsemode particles is also possible over land by comparing the path radiances at 660 and $470 \mathrm{~nm}$. Therefore, FM can also be obtained over land and coastal areas.

The validation of MODIS aerosol products is usually achieved by comparing them with the AERONET AOD data [22]. The retrieval accuracy is $( \pm 0.05 \pm 0.2 \mathrm{AOD})$ over land [23] and $( \pm 0.03 \pm 0.05$ AOD) over ocean [24]. Over land, even larger errors can be found in coastal zones due to subpixel water contamination. This effect tends to produce AOD overestimation [21]. Similarly, a significant water-color contribution can reduce the ocean AOD retrieval quality in coastal areas. At higher AOD values accompanied with desert aerosols larger uncertainty is caused in their retrieval due to the complexity of the dust nonsphericity problem [24, 25]. Analyzing numerous Mediterranean sites, Remer et al. [24] indicated that the particle size-dependent parameters (such as FM) are retrieved with an accuracy of $\pm 25 \%$. Even though both $\mathrm{AOD}_{550}$ and $\mathrm{FM}$ values corresponding to new Collection 5 datasets $[20,26]$ are more accurate than the previous version, Collection 4 [27], shows an overestimation for low $\mathrm{AOD}_{550}$ values and underestimation for high $\mathrm{AOD}_{550}$ values compared to AERONET retrievals. Unfortunately, such an intercomparison cannot be performed over Athens during the study period because of lack of ground-based data.

The MODIS aerosol products $\left(\mathrm{AOD}_{550}\right.$ and $\left.\mathrm{FM}\right)$ provided over Athens in a spatial resolution of $1^{\circ} \times 1^{\circ}$ (Level 3). A total of 1804 daily data were collected from 26 February 2000 to 31 December 2005 [17, 18]. The winter, spring, summer, and autumn days represent the $20.8 \%, 25.7 \%, 28.4 \%$, and $25.1 \%$ of the whole dataset, respectively. Thanks to the longterm period (2000-2005) the MODIS data are employed to evaluate the seasonal variability of the aerosol types over the region.

2.2. HYSLPIT Retrievals. The HYSPLIT model [28] is used for the identification of the main sectors, which favors the presence of specific aerosol types over Athens. Three different altitudes are used for the sector discrimination since the various aerosol types over Mediterranean coming from different directions are mainly transported in different 
altitudes. Air mass back-trajectories ending at Athens at three altitudes, 500, 1000, and $4000 \mathrm{~m}$ a.s.l., are calculated by the HYSPLIT model including model vertical wind. The National Center for Environmental Prediction (NCEP) reanalysis is used as model input. The HYSPLIT back trajectories refer to 11:00 UTC close to the Terra-MODIS overpass, on a daily basis. Previous investigations on Saharan dust outbreaks in Athens [29] and Northern Greece [30] showed that the dust outflow from the Sahara to the Eastern Mediterranean occurs mainly in the first $4-5 \mathrm{~km}$. Therefore, the selection of the $4000 \mathrm{~m}$ altitude for the identification of the Saharan dust particles is appropriate. The trajectory ending at $1000 \mathrm{~m}$ is associated with cases of dust transported in the lower atmospheric layers, or when the mixed layer is low as in winter [31], conversely, when air masses originate from other regions (e.g., continental Europe) are generally observed within the lowest $2-3 \mathrm{~km}$ [11].

\section{Methodology}

3.1. Identification of the Aerosol Types. In order to reduce the complexity of the aerosol field, some general types can be determined depending on the aerosol origin and optical properties. Over Athens, three main aerosol types are expected to be dominant in the atmospheric load: (1) continental aerosols produced by local industries, anthropogenic activities, or seasonal forest fires, (2) maritime aerosols produced at the sea surface by the winds, and (3) desert dust originating from the North African arid regions. Due to their different origins, these aerosol types generally show remarkably different optical and physicochemical characteristics [32]. More specifically, in urban environments aerosol optical properties are dominated by fine-mode particles [33], while desert dust is strongly contaminated by coarse particles [34]. In marine environments, the relative contribution of coarse particles, although variable [35], is general higher than in urban atmospheres and lower than for desert dust. A method originally proposed by Barnaba and Gobbi [4] was implemented to distinguish three main aerosol types over Athens, urban/industrial (UI), clean maritime (CM), and desert dust (DD). Based on the combination of $\mathrm{AOD}_{550}$ and $\mathrm{FM}$ values, the presence of the three aerosol types was separated over Athens on seasonal basis [17]. The method was based on the sensitivity of the two parameters to different, somewhat independent, microphysical aerosol properties: the fine-mode fraction depends on the size of the particles, while $\mathrm{AOD}_{550}$ depends both on the aerosol column density and, secondarily, on size. For the identification of UI aerosols the $\mathrm{AOD}_{550}$ values above 0.2 associated with significant FM contribution to the total AOD (above 80\%) were obtained, while the threshold values for the DD aerosols were $\mathrm{AOD}_{550}>$ 0.3 and $\mathrm{FM}<0.6$. The $\mathrm{CM}$ conditions occurred for $\mathrm{AOD}_{550}<0.2$ and $\mathrm{FM}<0.7$. The cases not belonging in any of these groups are characterized as "undetermined" (mixed) aerosols and have been excluded from the present analysis. It was found [17] that these cases constitute the $46.6 \%$ of the whole dataset (842 out of 1804). The remaining 442 cases $(24.5 \%)$ belong to the UI type, 183 $(10.2 \%)$ correspond to CM conditions, while 337 (18.7\%) to DD. Because of its simplicity, the discrimination method used is associated with some arbitrariness (e.g., incorrect aerosol-type interpretation), particularly at the threshold values between the aerosol types. However, the inclusion of the "undetermined" aerosol type takes provision for overestimating the presence of UI, CM, or DD aerosols. Despite its simplicity, this scheme seems to be appropriate for the aerosol discrimination over Athens as previous studies proved [17, 18]. Moreover, it was found that the UI aerosols are associated with air masses from the European sector, the $\mathrm{CM}$ conditions with fast moving Atlantic air masses, while the coarse-mode aerosols, probably DD, were related with air masses from the African continent. All the above give credit to the validity of the discrimination scheme and the relationship between the different aerosol types with air masses from their favorable sector. All these are quite important especially in the absence of ground-based measurements for justification of the satellite retrievals. However, the present results are in close agreement with previous studies over Eastern Mediterranean and Greece, which used ground-based measurements.

3.2. Identification of the Aerosol Origin. Four-day back trajectories ending at Athens were calculated by means of the HYSPLIT dispersion model to identify the origin of the air masses. The 4-day analysis seems to be appropriate for the scope of the study, since the air masses can be transported over long distances, such as North Atlantic and Europe before reaching over Athens. Furthermore, it was found that the use of 4 or 6 days does not significantly deviate the results. Each computed trajectory is associated with the corresponding aerosol optical characteristics. However, relating columnintegrated quantities to trajectories at specific altitudes maybe problematic and does not give a clear view of the dominant aerosol type. It was found that the definition of the sector might be different proportionally to the air mass altitude used. Therefore, great differences in the aerosol origin may be revealed if the analysis is based on back trajectories in the free troposphere $(4000 \mathrm{~m})$ or in the boundary layer $(1000$ and $500 \mathrm{~m})$. This investigation constitutes the main goal of the present study. Nevertheless, back trajectories have been widely used in connection with aerosol optical depth and Ångström exponent [36-38] in order to identify various aerosol types. For the investigation of the main pathways favoring the presence of each aerosol type over Athens, five geographical sectors are defined (Figure 1) in relation to different aerosol sources. The selected sectors are the following:

(a) a Southern sector, associated with the African region; the main source is the Sahara desert;

(b) a Western sector, which includes the Western Mediterranean basin, the Atlantic Ocean, the Iberian Peninsula, and Western France; the main aerosol type is of marine origin; 


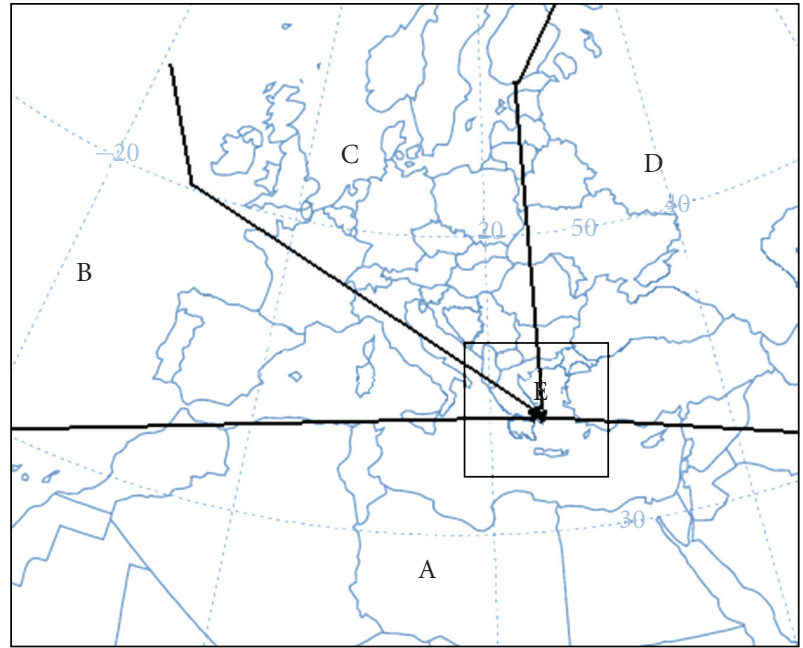

FIGURE 1: Separation of the regions acting as origins for the air masses ending at GAA. The location of GAA is indicated by an asterisk.

(c) a North, Northwestern sector, including CentralWestern Europe; the dominant aerosols are of anthropogenic origin;

(d) a North, Northeastern sector, including Eastern Europe and former Soviet Union counties; the aerosols are expected to be of anthropogenic origin or seasonal forest fires;

(e) a local sector including continental Greece and neighboring Balkan countries, Aegean Sea, and the Libyan Sea; the dominant aerosol type is of local emissions (mainly anthropogenic) and in some cases dust transported from Libya.

However, a degree of arbitrariness in the definition of the sectors exists, due to the effective distribution of the sources. Nevertheless, Pace et al. [36] showed that a little change in the borders of the sectors does not significantly affect the results on climatological basis. Also, they found that the use of different back-trajectories with varying duration (3 or 7 days) does not significantly modify the average optical properties in each sector. Therefore, the simple trajectory classification scheme (Figure 1) appears sufficiently robust to allow the identification of the main aerosol types. Previous studies (e.g., [39]) identified the air-mass origin sector by considering the time spent along the trajectory or using more sophisticated correlation methodologies [39] or cluster analysis [30]. Furthermore, previous results showed that dust could be detected even after a quick passage over the African continent [40]. Therefore, the time spent in each sector or the start of the air mass 4 days before reaching over Athens does not always provide reliable information about the aerosol origin. For this reason a different method was used to identify the air mass sector, taking into account the altitude of the air trajectories and possible interactions with the boundary layer. The same method has been developed and used by Pace et al. [36] and Meloni et al. [31], while an extensive description is given there. Nevertheless, a briefly overview is provided here.

It is assumed that the aerosol origin is confined to the mixed layer at the source location, when the air mass is inside the mixed layer at the source location. When this is not the case, the source of the trajectory is defined in the sector where the air mass interacts with the mixed layer. This criterion is satisfied when the air mass altitude is lower or close to the altitude of the mixed layer. The mixed layer is defined by the HYSPLIT model as the height where the potential temperature first exceeds the surface value by $2 \mathrm{~K}$, while a minimum value of $250 \mathrm{~m}$ is assumed [36]. If this condition is met more than once and at different sectors along the trajectory path, the sector is defined as the one where the air mass spends most of the time inside the boundary layer. In almost all the cases (95\%) this criterion was satisfied for the air masses ending at $1000 \mathrm{~m}$, while for $70 \%$ of the air masses ending at $4000 \mathrm{~m}$ this criterion was not met. Nevertheless, the majority of the air masses at $4000 \mathrm{~m}$ coming from North Africa satisfy this criterion, since the mixed-layer altitude is much larger over the African continent [31]. In the cases where the above criterion is not satisfied, the sector is defined as the one where the air mass spends more time. In order to include an air mass to B sector, it must spend more than $\sim 75 \%$ of the 4 days above sea surface (Atlantic Ocean and/or Mediterranean Sea).

\section{Results and Discussion}

In the present study the aerosol properties $\left(\mathrm{AOD}_{550}\right.$ and $\left.\mathrm{FM}\right)$ are computed over Athens for each sector and trajectory altitude, separately. It is obvious (see Tables 1, 2, 3, and 4) that the number of occurrences in each sector and the mean $\mathrm{AOD}_{550}$ and $\mathrm{FM}$ values differentiate proportionally to the air-mass altitude used for the sector definition. Therefore, the choice of the air-mass altitude constitutes the most complicated parameter for the sector identification and, as a consequence, the investigation on the computed differences constitutes a real challenge.

4.1. Seasonal Distribution of the Back Trajectories. Table 1 summarizes the number of occurrences in each sector based on the three altitudes selected. Regarding the whole dataset (Table 1) it is concluded that the choice of the air-trajectory altitude for the sector identification plays a very crucial role, since large variations can emerge for the air masses traveling within the boundary layer and in the free troposphere. Regarding the lower altitude $(500 \mathrm{~m})$ it is seen that the majority of the air masses correspond to Northwestern (33\%) and Northern (30\%) directions, while these originating from the Atlantic Ocean are very few (only $9 \%)$. A rather significant fraction $(16 \%)$ corresponds to air masses of Saharan origin, thus leading to vertical dust transport [41]. It is also worth noticing that the majority of the cases belonging to local emissions (sector E) correspond to air masses in the lower atmospheric layers. As the altitude increases, the air mass changes sector with preference to western directions due to the dominant western flow in the 
TABLE 1: Mean values of $\mathrm{AOD}_{550}$ and FM fraction for all aerosol types over GAA. These values correspond to the whole dataset. The number and the relative frequency of the trajectories from each sector are also given for the three altitude levels: $500 \mathrm{~m}, 1000 \mathrm{~m}$, and $4000 \mathrm{~m}$.

\begin{tabular}{|c|c|c|c|c|c|c|c|c|}
\hline Traje & tude & $\mathrm{AOD}_{550}$ & FM & Year & Winter & Spring & Summer & Autumn \\
\hline \multirow{5}{*}{$500 \mathrm{~m}$} & A & $0.38 \pm 0.13$ & $0.61 \pm 0.10$ & $155(16 \%)$ & $16 \%$ & $25 \%$ & $25 \%$ & $34 \%$ \\
\hline & B & $0.34 \pm 0.10$ & $0.58 \pm 0.12$ & 87 (9\%) & $33 \%$ & $18 \%$ & $20 \%$ & $29 \%$ \\
\hline & C & $0.36 \pm 0.16$ & $0.59 \pm 0.12$ & $317(33 \%)$ & $16 \%$ & $21 \%$ & $39 \%$ & $24 \%$ \\
\hline & $\mathrm{D}$ & $0.39 \pm 0.11$ & $0.65 \pm 0.10$ & $285(30 \%)$ & $8 \%$ & $33 \%$ & $35 \%$ & $24 \%$ \\
\hline & $\mathrm{E}$ & $0.37 \pm 0.10$ & $0.64 \pm 0.09$ & $118(12 \%)$ & $8 \%$ & $34 \%$ & $26 \%$ & $31 \%$ \\
\hline \multirow{5}{*}{$1000 \mathrm{~m}$} & A & $0.38 \pm 0.12$ & $0.61 \pm 0.10$ & $196(20 \%)$ & $15 \%$ & $26 \%$ & $24 \%$ & $36 \%$ \\
\hline & B & $0.34 \pm 0.09$ & $0.58 \pm 0.12$ & $108(11 \%)$ & $28 \%$ & $15 \%$ & $25 \%$ & $32 \%$ \\
\hline & C & $0.36 \pm 0.17$ & $0.60 \pm 0.12$ & $333(35 \%)$ & $15 \%$ & $24 \%$ & $39 \%$ & $23 \%$ \\
\hline & $\mathrm{D}$ & $0.39 \pm 0.12$ & $0.65 \pm 0.10$ & $228(24 \%)$ & $8 \%$ & $32 \%$ & $36 \%$ & $23 \%$ \\
\hline & E & $0.37 \pm 0.11$ & $0.65 \pm 0.11$ & $97(10 \%)$ & $10 \%$ & $32 \%$ & $26 \%$ & $32 \%$ \\
\hline \multirow{5}{*}{$4000 \mathrm{~m}$} & A & $0.39 \pm 0.13$ & $0.60 \pm 0.12$ & $233(24 \%)$ & $16 \%$ & $31 \%$ & $25 \%$ & $27 \%$ \\
\hline & B & $0.34 \pm 0.10$ & $0.60 \pm 0.12$ & $477(50 \%)$ & $16 \%$ & $23 \%$ & $32 \%$ & $29 \%$ \\
\hline & C & $0.35 \pm 0.09$ & $0.63 \pm 0.10$ & $166(17 \%)$ & $10 \%$ & $25 \%$ & $40 \%$ & $25 \%$ \\
\hline & $\mathrm{D}$ & $0.37 \pm 0.11$ & $0.63 \pm 0.12$ & $51(5 \%)$ & $8 \%$ & $41 \%$ & $31 \%$ & $20 \%$ \\
\hline & E & $0.40 \pm 0.16$ & $0.65 \pm 0.11$ & $35(4 \%)$ & $0 \%$ & $23 \%$ & $49 \%$ & $29 \%$ \\
\hline
\end{tabular}

TABle 2: As in Table 1, but for the UI aerosols.

\begin{tabular}{|c|c|c|c|c|c|c|c|c|}
\hline \multicolumn{2}{|c|}{ Trajectory altitude } & \multirow{2}{*}{$\frac{\mathrm{AOD}_{550}}{0.45 \pm 0.12}$} & \multirow{2}{*}{$\frac{F M}{0.88 \pm 0.06}$} & \multirow{2}{*}{$\begin{array}{c}\text { Year } \\
40(9 \%)\end{array}$} & \multirow{2}{*}{$\begin{array}{c}\text { Winter } \\
5 \%\end{array}$} & \multirow{2}{*}{$\begin{array}{c}\text { Spring } \\
48 \%\end{array}$} & \multirow{2}{*}{$\begin{array}{c}\text { Summer } \\
23 \%\end{array}$} & \multirow{2}{*}{$\begin{array}{c}\text { Autumn } \\
25 \%\end{array}$} \\
\hline & A & & & & & & & \\
\hline & B & $0.45 \pm 0.29$ & $0.89 \pm 0.08$ & $14(3 \%)$ & $14 \%$ & $64 \%$ & $14 \%$ & $7 \%$ \\
\hline \multirow[t]{5}{*}{$500 \mathrm{~m}$} & $\mathrm{C}$ & $0.42 \pm 0.13$ & $0.89 \pm 0.07$ & $120(27 \%)$ & $8 \%$ & $42 \%$ & $34 \%$ & $17 \%$ \\
\hline & $\mathrm{D}$ & $0.46 \pm 0.13$ & $0.89 \pm 0.08$ & $198(45 \%)$ & $8 \%$ & $44 \%$ & $25 \%$ & $24 \%$ \\
\hline & $\mathrm{E}$ & $0.44 \pm 0.13$ & $0.89 \pm 0.07$ & $70(16 \%)$ & $7 \%$ & $37 \%$ & $21 \%$ & $34 \%$ \\
\hline & A & $0.44 \pm 0.12$ & $0.88 \pm 0.06$ & $65(14 \%)$ & $6 \%$ & $45 \%$ & $14 \%$ & $35 \%$ \\
\hline & B & $0.45 \pm 0.32$ & $0.87 \pm 0.08$ & $12(3 \%)$ & $17 \%$ & $67 \%$ & $17 \%$ & $0 \%$ \\
\hline \multirow[t]{5}{*}{$1000 \mathrm{~m}$} & C & $0.43 \pm 0.12$ & $0.89 \pm 0.08$ & $145(33 \%)$ & $6 \%$ & $41 \%$ & $38 \%$ & $14 \%$ \\
\hline & $\mathrm{D}$ & $0.46 \pm 0.13$ & $0.90 \pm 0.07$ & $159(37 \%)$ & $8 \%$ & $45 \%$ & $23 \%$ & $25 \%$ \\
\hline & $\mathrm{E}$ & $0.46 \pm 0.14$ & $0.88 \pm 0.07$ & $62(13 \%)$ & $10 \%$ & $40 \%$ & $23 \%$ & $27 \%$ \\
\hline & A & $0.47 \pm 0.14$ & $0.88 \pm 0.09$ & $93(21 \%)$ & $16 \%$ & $45 \%$ & $15 \%$ & $24 \%$ \\
\hline & B & $0.44 \pm 0.14$ & $0.89 \pm 0.07$ & $209(47 \%)$ & $4 \%$ & $43 \%$ & $33 \%$ & $20 \%$ \\
\hline \multirow[t]{3}{*}{$4000 \mathrm{~m}$} & $\mathrm{C}$ & $0.44 \pm 0.11$ & $0.90 \pm 0.06$ & 86 (19\%) & $8 \%$ & $41 \%$ & $26 \%$ & $26 \%$ \\
\hline & $\mathrm{D}$ & $0.46 \pm 0.14$ & $0.89 \pm 0.07$ & $34(8 \%)$ & $6 \%$ & $59 \%$ & $21 \%$ & $15 \%$ \\
\hline & $\mathrm{E}$ & $0.48 \pm 0.14$ & $0.89 \pm 0.09$ & $21(5 \%)$ & $0 \%$ & $33 \%$ & $29 \%$ & $38 \%$ \\
\hline
\end{tabular}

free troposphere occurring in the temperate zone. Thus, the Atlantic air masses (sector B) represent $50 \%$ of the air masses over Athens in the free troposphere $(4000 \mathrm{~m})$. Furthermore, a large fraction (24\%) corresponds to African air masses, suggesting that the Saharan outflow over Eastern Mediterranean occurs mainly in the free troposphere. On the other hand, only few cases correspond to air masses from Northeast or local origin at $4000 \mathrm{~m}$.

Very interesting findings can be revealed when the above analysis is performed for each season. In Figure 2 the seasonal frequency distribution (\%) of the air masses is given for any altitude and sector together with the number of available cases, N. In winter, the majority of the air masses, specifically at $4000 \mathrm{~m}$, belong to Sector B, further verifying the clean atmospheric conditions occurred in this season [18]. This distribution is essentially produced by the annual evolution of the meteorological synoptic patterns over the Eastern Mediterranean, with strong Northwestern and Western winds in winter as a consequence of the cyclonic circulation patterns. The Saharan air masses exhibit almost the same frequency with the $\mathrm{C}$ sector while that of the other two directions is very low. In spring and summer the above situation is clearly reversed since the majority of the air masses influencing Athens belong to the Northwestern and Northeastern directions, especially for air masses within the boundary layer. In summer, a strong North pressure gradient 
TABle 3: As in Table 1, but for the CM aerosols.

\begin{tabular}{|c|c|c|c|c|c|c|c|c|}
\hline \multicolumn{2}{|c|}{ Trajectory altitude } & \multirow{2}{*}{$\frac{\mathrm{AOD}_{550}}{0.15 \pm 0.04}$} & \multirow{2}{*}{$\frac{\text { FM }}{0.51 \pm 0.09}$} & \multirow{2}{*}{$\frac{\text { Year }}{27(15 \%)}$} & \multirow{2}{*}{$\begin{array}{c}\text { Winter } \\
48 \%\end{array}$} & \multirow{2}{*}{$\begin{array}{c}\text { Spring } \\
4 \%\end{array}$} & \multirow{2}{*}{$\begin{array}{c}\text { Summer } \\
0 \%\end{array}$} & \multirow{2}{*}{$\begin{array}{c}\text { Autumn } \\
48 \%\end{array}$} \\
\hline \multirow{5}{*}{$500 \mathrm{~m}$} & A & & & & & & & \\
\hline & $\mathrm{B}$ & $0.13 \pm 0.04$ & $0.46 \pm 0.14$ & $47(26 \%)$ & $55 \%$ & $11 \%$ & $0 \%$ & $34 \%$ \\
\hline & $\mathrm{C}$ & $0.14 \pm 0.04$ & $0.47 \pm 0.16$ & $77(43 \%)$ & $52 \%$ & $10 \%$ & $13 \%$ & $25 \%$ \\
\hline & $\mathrm{D}$ & $0.16 \pm 0.03$ & $0.60 \pm 0.09$ & $17(9 \%)$ & $35 \%$ & $12 \%$ & $18 \%$ & $35 \%$ \\
\hline & $\mathrm{E}$ & $0.15 \pm 0.03$ & $0.58 \pm 0.10$ & $14(7 \%)$ & $29 \%$ & $64 \%$ & $7 \%$ & $0 \%$ \\
\hline \multirow{5}{*}{$1000 \mathrm{~m}$} & A & $0.15 \pm 0.03$ & $0.51 \pm 0.10$ & $30(17 \%)$ & $53 \%$ & $7 \%$ & $0 \%$ & $40 \%$ \\
\hline & $\mathrm{B}$ & $0.12 \pm 0.04$ & $0.46 \pm 0.14$ & $50(27 \%)$ & $54 \%$ & $6 \%$ & $2 \%$ & $38 \%$ \\
\hline & $\mathrm{C}$ & $0.14 \pm 0.04$ & $0.49 \pm 0.16$ & $81(45 \%)$ & $47 \%$ & $14 \%$ & $14 \%$ & $26 \%$ \\
\hline & $\mathrm{D}$ & $0.15 \pm 0.03$ & $0.59 \pm 0.10$ & $13(7 \%)$ & $46 \%$ & $0 \%$ & $8 \%$ & $46 \%$ \\
\hline & $\mathrm{E}$ & $0.15 \pm 0.04$ & $0.58 \pm 0.13$ & $8(4 \%)$ & $25 \%$ & $0 \%$ & $13 \%$ & $63 \%$ \\
\hline \multirow{5}{*}{$4000 \mathrm{~m}$} & A & $0.14 \pm 0.03$ & $0.47 \pm 0.15$ & $22(12 \%)$ & $59 \%$ & $9 \%$ & $0 \%$ & $32 \%$ \\
\hline & $\mathrm{B}$ & $0.13 \pm 0.04$ & $0.49 \pm 0.15$ & $127(70 \%)$ & $50 \%$ & $8 \%$ & $5 \%$ & $37 \%$ \\
\hline & $\mathrm{C}$ & $0.16 \pm 0.04$ & $0.54 \pm 0.12$ & $26(14 \%)$ & $38 \%$ & $15 \%$ & $23 \%$ & $23 \%$ \\
\hline & $\mathrm{D}$ & $0.15 \pm 0.04$ & $0.55 \pm 0.17$ & $5(3 \%)$ & $40 \%$ & $0 \%$ & $40 \%$ & $20 \%$ \\
\hline & $\mathrm{E}$ & $0.13 \pm 0.09$ & $0.62 \pm 0.10$ & $2(1 \%)$ & $0 \%$ & $0 \%$ & $0 \%$ & $100 \%$ \\
\hline
\end{tabular}

TABle 4: As in Table 1, but for the DD aerosols.

\begin{tabular}{|c|c|c|c|c|c|c|c|c|}
\hline \multicolumn{2}{|c|}{ Trajectory altitude } & \multirow{2}{*}{$\frac{\mathrm{AOD}_{550}}{0.53 \pm 0.22}$} & \multirow{2}{*}{$\frac{F M}{0.43 \pm 0.15}$} & \multirow{2}{*}{$\frac{\text { Year }}{88(26 \%)}$} & \multirow{2}{*}{$\begin{array}{c}\text { Winter } \\
11 \%\end{array}$} & \multirow{2}{*}{$\frac{\text { Spring }}{22 \%}$} & \multirow{2}{*}{$\begin{array}{c}\text { Summer } \\
33 \%\end{array}$} & \multirow{2}{*}{$\begin{array}{c}\text { Autumn } \\
34 \%\end{array}$} \\
\hline & $\mathrm{A}$ & & & & & & & \\
\hline & $\mathrm{B}$ & $0.45 \pm 0.15$ & $0.40 \pm 0.13$ & $26(8 \%)$ & $4 \%$ & $8 \%$ & $58 \%$ & $31 \%$ \\
\hline \multirow[t]{5}{*}{$500 \mathrm{~m}$} & $\mathrm{C}$ & $0.45 \pm 0.14$ & $0.41 \pm 0.14$ & $120(36 \%)$ & $1 \%$ & $8 \%$ & $61 \%$ & $30 \%$ \\
\hline & $\mathrm{D}$ & $0.54 \pm 0.17$ & $0.46 \pm 0.12$ & $69(20 \%)$ & $1 \%$ & $7 \%$ & $70 \%$ & $22 \%$ \\
\hline & $\mathrm{E}$ & $0.51 \pm 0.13$ & $0.46 \pm 0.10$ & $34(10 \%)$ & $3 \%$ & $15 \%$ & $44 \%$ & $38 \%$ \\
\hline & A & $0.54 \pm 0.21$ & $0.43 \pm 0.14$ & $101(30 \%)$ & $9 \%$ & $19 \%$ & $38 \%$ & $35 \%$ \\
\hline & $\mathrm{B}$ & $0.44 \pm 0.14$ & $0.40 \pm 0.13$ & $46(14 \%)$ & $2 \%$ & $11 \%$ & $52 \%$ & $35 \%$ \\
\hline \multirow[t]{5}{*}{$1000 \mathrm{~m}$} & $\mathrm{C}$ & $0.46 \pm 0.12$ & $0.42 \pm 0.14$ & $107(32 \%)$ & $2 \%$ & $7 \%$ & $59 \%$ & $32 \%$ \\
\hline & $\mathrm{D}$ & $0.55 \pm 0.19$ & $0.46 \pm 0.12$ & $56(16 \%)$ & $0 \%$ & $5 \%$ & $80 \%$ & $14 \%$ \\
\hline & $\mathrm{E}$ & $0.50 \pm 0.16$ & $0.48 \pm 0.13$ & $27(8 \%)$ & $7 \%$ & $22 \%$ & $37 \%$ & $33 \%$ \\
\hline & A & $0.57 \pm 0.21$ & $0.45 \pm 0.13$ & $118(35 \%)$ & $8 \%$ & $25 \%$ & $38 \%$ & $29 \%$ \\
\hline & $\mathrm{B}$ & $0.44 \pm 0.12$ & $0.41 \pm 0.14$ & $141(42 \%)$ & $3 \%$ & $6 \%$ & $56 \%$ & $35 \%$ \\
\hline \multirow[t]{3}{*}{$4000 \mathrm{~m}$} & $\mathrm{C}$ & $0.45 \pm 0.12$ & $0.46 \pm 0.13$ & $54(17 \%)$ & $0 \%$ & $4 \%$ & $70 \%$ & $26 \%$ \\
\hline & $\mathrm{D}$ & $0.49 \pm 0.15$ & $0.46 \pm 0.13$ & $12(3 \%)$ & $0 \%$ & $8 \%$ & $58 \%$ & $33 \%$ \\
\hline & $\mathrm{E}$ & $0.59 \pm 0.24$ & $0.45 \pm 0.15$ & $12(3 \%)$ & $0 \%$ & $8 \%$ & $92 \%$ & $0 \%$ \\
\hline
\end{tabular}

is developed over the Aegean Sea as a consequence of the combined effects of the North Balkan high-pressure system with the low-pressure one developed in Eastern Levantine Basin. This pressure pattern is associated with air masses from the Northern Balkan countries, whilst the Etesians are quite strong in many cases. These winds carry either pollution and biomass-burning aerosols, affecting mainly Northern Greece $[42,43]$, or sea-spray particles from the Aegean Sea before reaching Athens. This is the reason for the dominance of the D sector in late spring and summer. Our results are in agreement with those of Stohl et al. [12] and Duncan and Bey [13], who show that the main continental outflow at the lower atmospheric levels towards the Eastern Mediterranean occurs during summer; this flow is greatly reduced during the other seasons. Also, a significant fraction (18\%-28\%) corresponds to air masses from Saharan desert especially at the 4000-m altitude. A recent work by Sciare et al. [44] investigated the contribution of different aerosol sources in the Eastern Mediterranean basin, showing that this region is influenced by a wide range of air masses originating mainly from Europe and Africa during summertime. In autumn all the sectors contribute almost in the same way to the air masses reaching Athens, with a shift towards West as the altitude increases. For a more detailed analysis in the followings, the air-mass classification is given for each aerosol type separately aiming at investigating about the main pathways favoring the presence of specific aerosol types over Athens. 

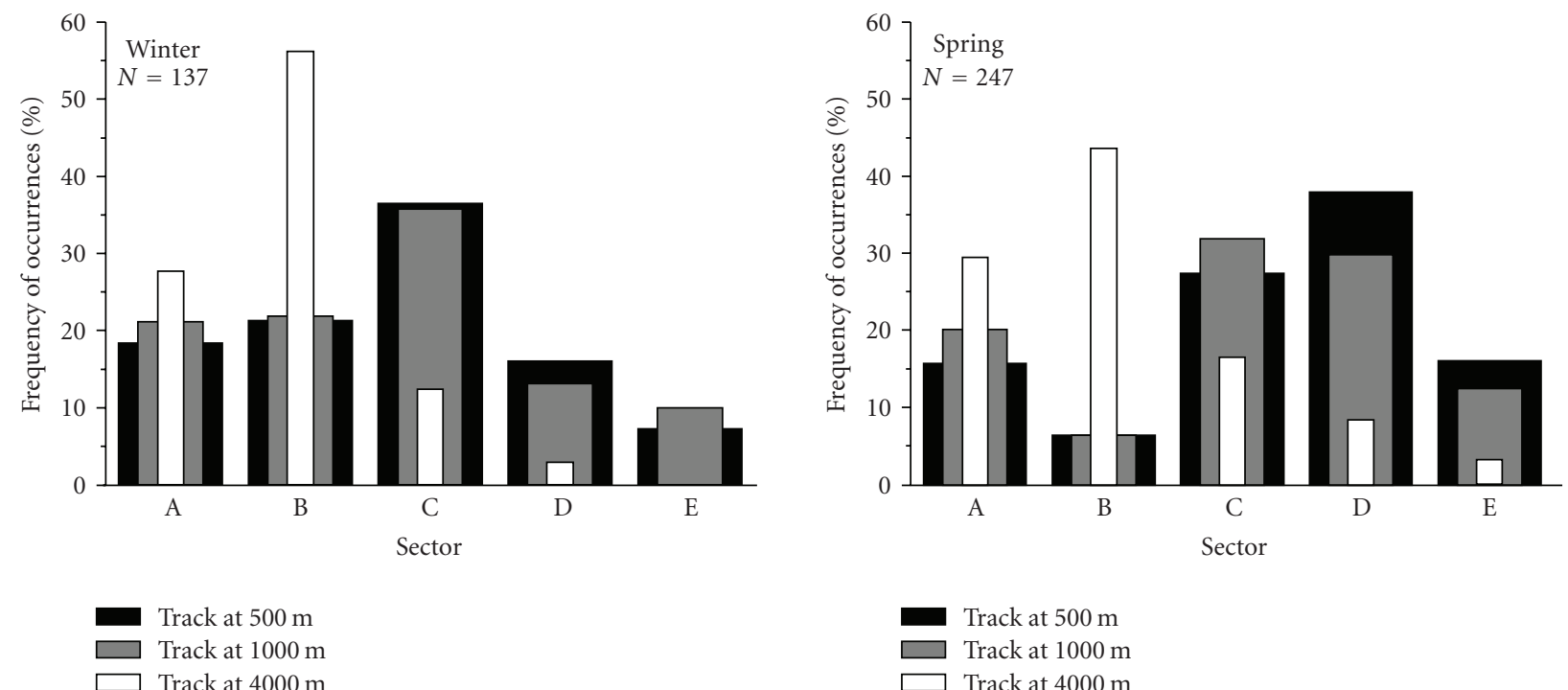

(a)

(b)
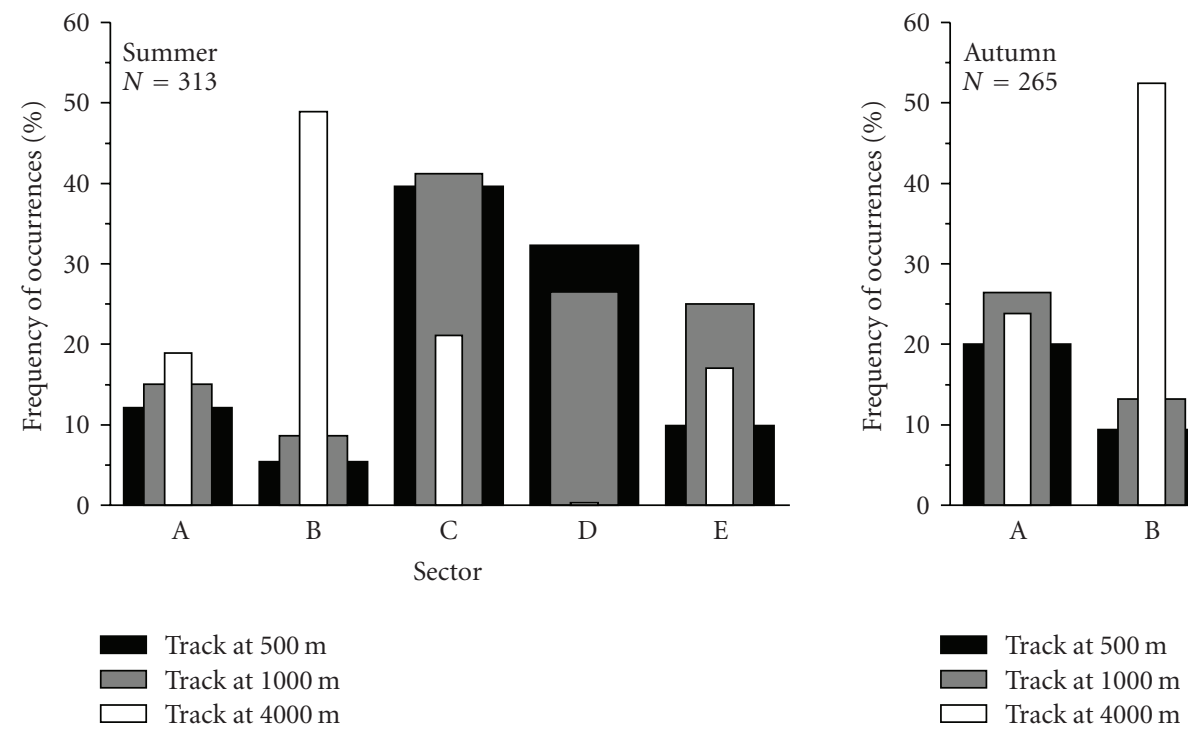

(c)

(d)

FIGURE 2: Seasonal frequency (\%) distribution of the air-mass trajectories at three atmospheric levels over GAA for the whole dataset. The number of data, $\mathrm{N}$, in each season is also given.

4.2. Main Sectors for the Occurrence of Each Aerosol Type. In this Section the above analysis is divided into three classes according to the dominant aerosol type over Athens and the criteria described in Section 3. For cases corresponding to the UI type, the majority of the trajectories belong to the Northeastern Sector (see Figure 3 and Table 2). The main finding regarding the favorable direction for UI type over Athens leads to a Northern flow, mainly from Eastern Europe, within the boundary layer $(500$ and $1000 \mathrm{~m})$. In contrast, the use of the air masses at $4000 \mathrm{~m}$ shows a preferable western and south direction in agreement with the western circulation patterns occurring in the free atmosphere at Northern mid latitudes. Note that a significant number of African air masses (9\%-21\%) can be characterized as
UI aerosols in the Athens urban environment. In these cases the Saharan outflow is weak and the boundary layer anthropogenic aerosols dominate. Therefore, the necessity of using vertical aerosol profiles in order to distinguish different aerosol types in an urban environment is obvious [29]. Air masses belonging to Sector A can have high FM values (such as 0.93) indicative of anthropogenic rather than Saharan dust aerosols. This fact was also obvious in Lampedusa [36] where in some cases dust-loading air masses were mixed with smoke aerosols from forest fires in the coastal areas of Algeria. Moreover, the occurrence of UI conditions is not favored by Atlantic air masses at the lower altitudes, since they strongly interact with the marine boundary layer. Inversely, a significant contribution 

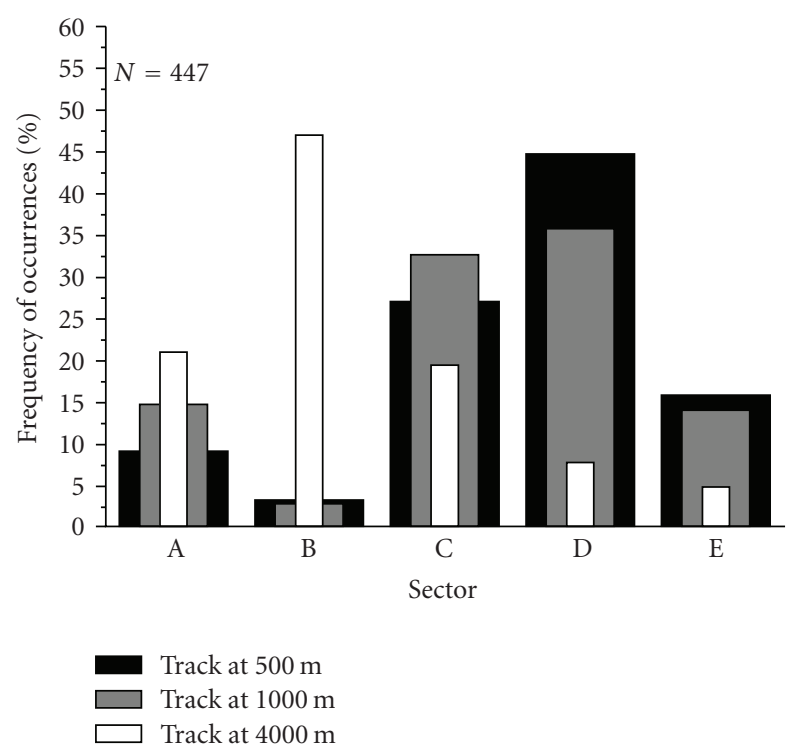

Figure 3: Frequency (\%) distribution of the air-mass trajectories at three atmospheric levels over GAA for the UI aerosol type. The number of data, $\mathrm{N}$, is also given.

to these conditions $(13 \%-16 \%)$ is provided by the local air masses within the boundary layer favored under stagnant atmospheric conditions. The air-trajectory pattern suggests a prevalent northerly flow at the lower altitudes, where transport of pollutants mainly occurs [42]. In addition, Lelieveld et al. [11] revealed a dominant northerly flow below $4 \mathrm{~km}$ in Crete, further confirming our results and those of Stohl et al. [12] and Duncan and Bey [13]. Conversely, in the middle and upper troposphere, Lelieveld et al. [11] found westerly/southerly winds to prevail over Crete. Similarly to the latter, the present analysis for the UI aerosol type over Athens reveals considerable influence from westerly air masses $(47 \%)$ at $4000 \mathrm{~m}$ compared to only $3 \%$ in the boundary layer (Table 2). The close agreement of the present results with those of previous studies supports the validity of the identification scheme for the aerosol type discrimination [17] and, in general, the satellite retrievals and the methodology used despite the lack of intercomparison with groundbased measurements.

Regarding the air masses favoring the presence of CM conditions over Athens (Figure 4, Table 3) it is obvious that the $\mathrm{B}$ and $\mathrm{C}$ Sectors dominate. The majority of the air masses from Sector B belong to the free troposphere $(4000 \mathrm{~m})$ for the reasons mentioned above. These results are in agreement with relevant studies in Northern Greece [30] who found more transparent atmospheric conditions associated with air masses from the Atlantic Ocean and Western Europe. Pay attention also to the very low frequencies related to the D and E Sectors, both favoring the trans-boundary pollution transport or the accumulation of aerosols. It is also worth mentioning the significant fraction of air masses from the African continent $(12 \%-17 \%)$ that, in general, do not favor the presence of clean atmospheres over Mediterranean. It was found that in these cases either is the dust outflow very weak or wet scavenging via precipitation occurs during its

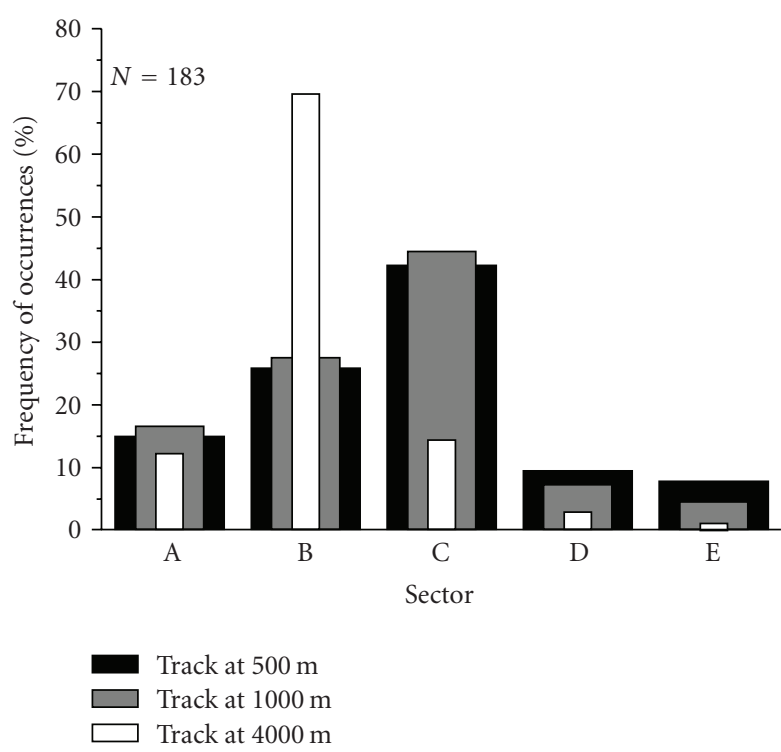

FIgURe 4: Same as in Figure 3, but for the CM aerosol type.

transport over Mediterranean before reaching Athens. It was also found that $70 \%$ of these cases include precipitation over Athens, while the majority of the air masses belonging to Sector C have initial Atlantic origin.

As expected, the DD aerosol type occurs mainly from air masses originating from the Sahara desert, especially for air trajectories at $4000 \mathrm{~m}$ (35\%, see Table 4). Thus, it is concluded that the $4000 \mathrm{~m}$ level for the identification of Saharan outflows is reliable as has also been suggested from a variety of studies $[40,45]$. The most unexpected feature is the high occurrence of air masses from C (32\%-36\%) and D (16\%-20\%) Sectors within the boundary layer $(1000 \mathrm{~m}$ and $500 \mathrm{~m}$ ), which favor the presence of DD type over Athens. As clearly mentioned above, only a fraction of the DD type corresponds to dust particles and the occurrence of such aerosols associated with a northern flow maybe related to sea-spray or soil coarse-mode particles lifted from the Aegean Sea and transported above Athens. There should be noticed the great differences in the occurrence of DD type revealed from the trajectory analysis (Figure 5). Thus, the Saharan dust aerosols originating from the Sector A are mainly identified by the trajectories at $4000 \mathrm{~m}$, while the coarse-mode particles from northern directions (mainly soil materials and sea spray) seem to travel within the boundary layer. As also expected, the presence of DD type associated with Atlantic air masses is low, mainly occurring in cases that these air masses (specifically at $4000 \mathrm{~m}$ ) pass near the African continent. It was also found (not presented) that nearly the whole of the air masses originating from Sector E, and associated with DD aerosols over Athens, come from the south direction (North Libyan Sea) enriched with desert particles.

The above fractions are strongly modified proportionally to the season, and this will be further analyzed. This seasonal variation is mainly driven by the meteorological and 

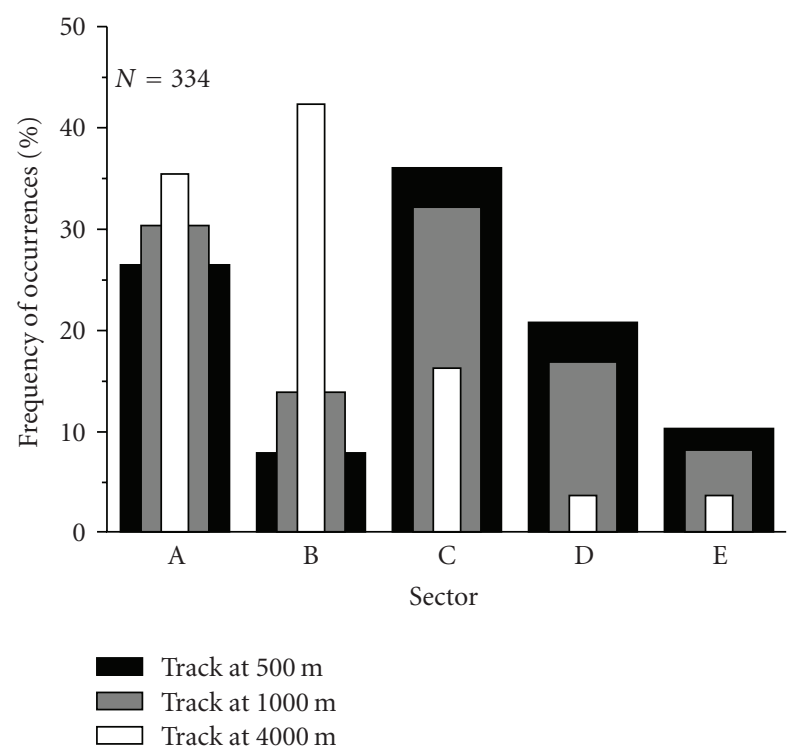

FIgURE 5: Same as in Figure 3, but for the DD aerosol type.

synoptic circulation patterns over Eastern Mediterranean, the local emissions, the meteorological fields favoring the dust outbreaks, the wind speed and direction, and the removal processes. The above analysis is repeated for each individual season in order to establish the differences in the frequency of occurrence for each Sector.

The dominance of UI type in spring is apparent in Figure $6(N=195)$. The back trajectory distribution of UI type in spring is closely related to the whole dataset (Figure 2). In winter, despite the low occurrence of the UI type $(N=34)$, its presence is favored by air masses from the $\mathrm{D}$ Sector for air masses within the boundary layer. The large occurrence of air masses from the B Sector at $4000 \mathrm{~m}$ is not associated with local pollution, which is mainly attributed to air masses in the boundary layer. Furthermore, significant contribution to the UI type is provided by the local stagnant air masses (Sector E) mainly in the warm period of the year.

Clean maritime conditions are rare over Athens, occurring mainly in winter, and are generally associated with air masses originating from North Atlantic and to a lesser extent from Western and Central Europe (Figure 7, Table 3). The $\mathrm{CM}$ cases belonging to Sector $\mathrm{C}$ are associated with fast-moving air masses exhibiting a descent trajectory when reaching Athens, thus not carrying air pollutants from Continental Europe. Note also that these air masses are very few in spring and summer, when they contribute to the transboundary air pollution (Figure 6). It is also worth noticing that in all seasons the CM conditions over Athens associated with Sectors D and E are nearly absent at any level. CM conditions can also be found from air masses originating from the African region. Note that nearly all of them occur in winter and autumn and none in summer. The majority of them are associated with wet removal processes before reaching Athens.

The most interesting features regarding the seasonal distribution of the trajectories are depicted for the DD type
(Figure 8, Table 4). Figure 8 gives support to our previous statements regarding different origins of the coarse-mode particles (referred to as DD) proportionally to the season. Thus, in winter nearly the whole of the DD cases are associated with air masses from Saharan origin (sector A). It is also worth noticing that the African air masses carry desert-dust aerosols at all altitudes favoring the vertical dust transport this season, a feature which is in close agreement with Kalivitis et al. [41] results. In spring, the Saharan contribution to the coarse particles remains the dominant process, with the only difference being the higher number of air masses at $4000 \mathrm{~m}$ (70\%) enhancing the dust transport in the free troposphere. In further contrast, in summer the above situation is reversed and the coarsemode particles are most associated with air masses from northern directions, Sectors $\mathrm{C}$ and D. The lower $\mathrm{AOD}_{550}$ values of the $\mathrm{DD}$ type in summer compared to the spring ones also verify our assumptions, as only part of these DD cases is associated with Saharan desert-dust particles. In early autumn, a similar situation seems to exist, while in late autumn the conditions approach those of winter. Therefore, in autumn similar percentages of the $\mathrm{C}$ and $\mathrm{A}$ Sectors take place. Regarding the Saharan outflow, the upper troposphere transport dominates in summer and the vertical in autumn, in agreement with the transport observed over Crete [41]. All the above findings are presented in Figure 9, where the differences in the occurrences of each aerosol type proportionally to the transport altitude are clearly depicted.

4.3. Back Trajectories and Aerosol Properties. In this section the $\mathrm{AOD}_{550}$ and $\mathrm{FM}$ values for each aerosol type are studied with respect to the back trajectories at the three altitudes selected. The mean and the standard deviations of the $\mathrm{AOD}_{550}$ and FM values are given in Tables 1, 2, 3 and 4 for the whole dataset, UI, CM, and DD aerosol types, respectively. The number of the available data is also given for each sector and air-mass altitude.

Values of $\mathrm{AOD}_{550}$ and $\mathrm{FM}$ averaged over the whole experimental period are about 0.38 and 0.61 for Sector A, while the lowest values $(\sim 0.34$ and $\sim 0.58)$ are associated with air masses from Sector B. The lowest $\mathrm{AOD}_{550}$ and $\mathrm{FM}$ from this sector are expected because of the dominance of marine aerosols. On the other hand, the highest $\mathrm{AOD}_{550}(\sim 0.37-$ $0.40)$ in conjunction with the highest FM values $(0.63-0.65)$ are associated with pollution air masses from Eastern Europe and local emissions (Sectors D and E, resp.). Zerefos et al. [43] showed enhanced columnar $\mathrm{SO}_{2}$ values over northern Greece that correspond to northeastern directions mainly during summertime, providing further evidence for the pollution transport. In addition, this sector has been also affected by severe biomass burning episodes [46]. Sector E is representative mostly for local circulation patterns, and therefore, the enhanced $\mathrm{AOD}_{550}$ and $\mathrm{FM}$ values should be attributed to local pollution with some enhancement at the higher altitudes by Saharan dust from Libya (see the higher $\mathrm{AOD}_{550}$ values at $4000 \mathrm{~m}$ ). Finally, a great part of the measurements at all altitudes (17\%-35\%) corresponds to Sector C, which is representative at northwestern flow from 

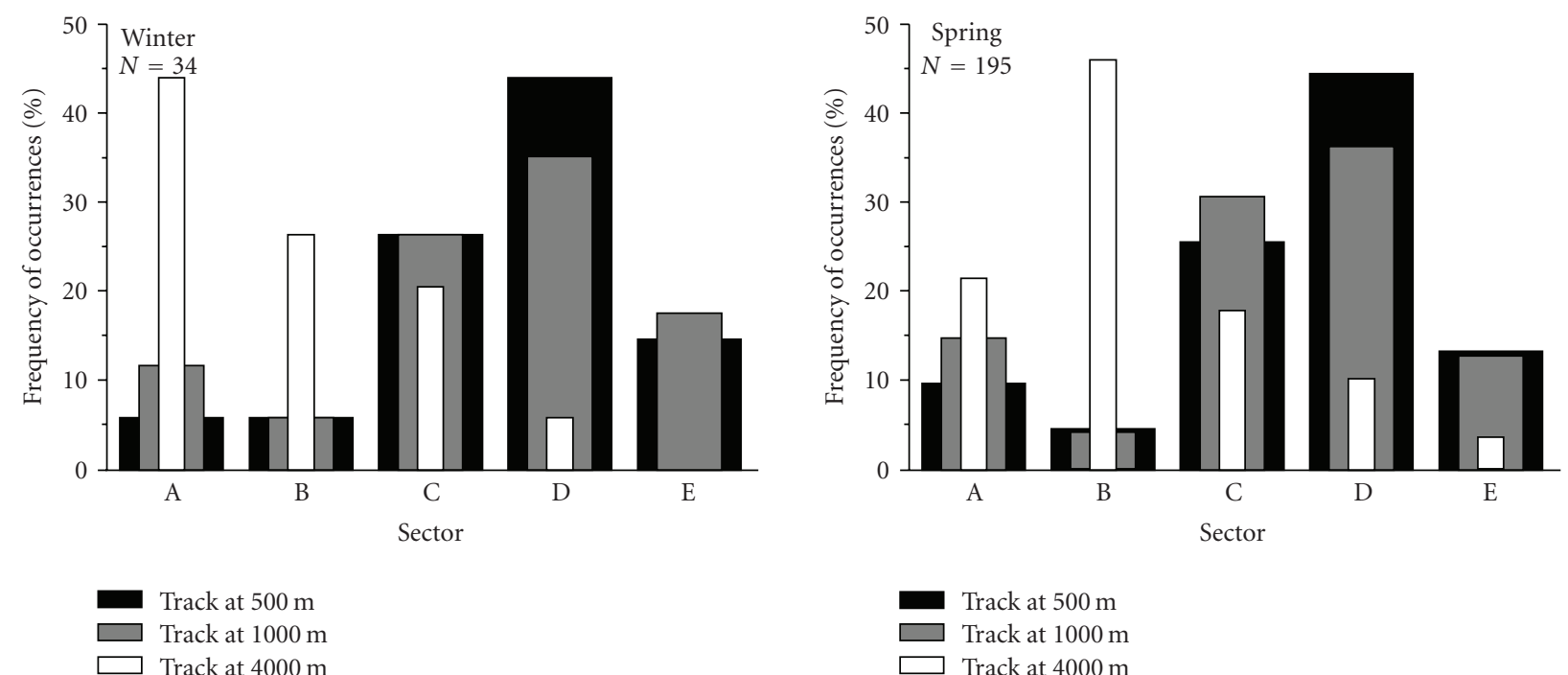

(a)

(b)
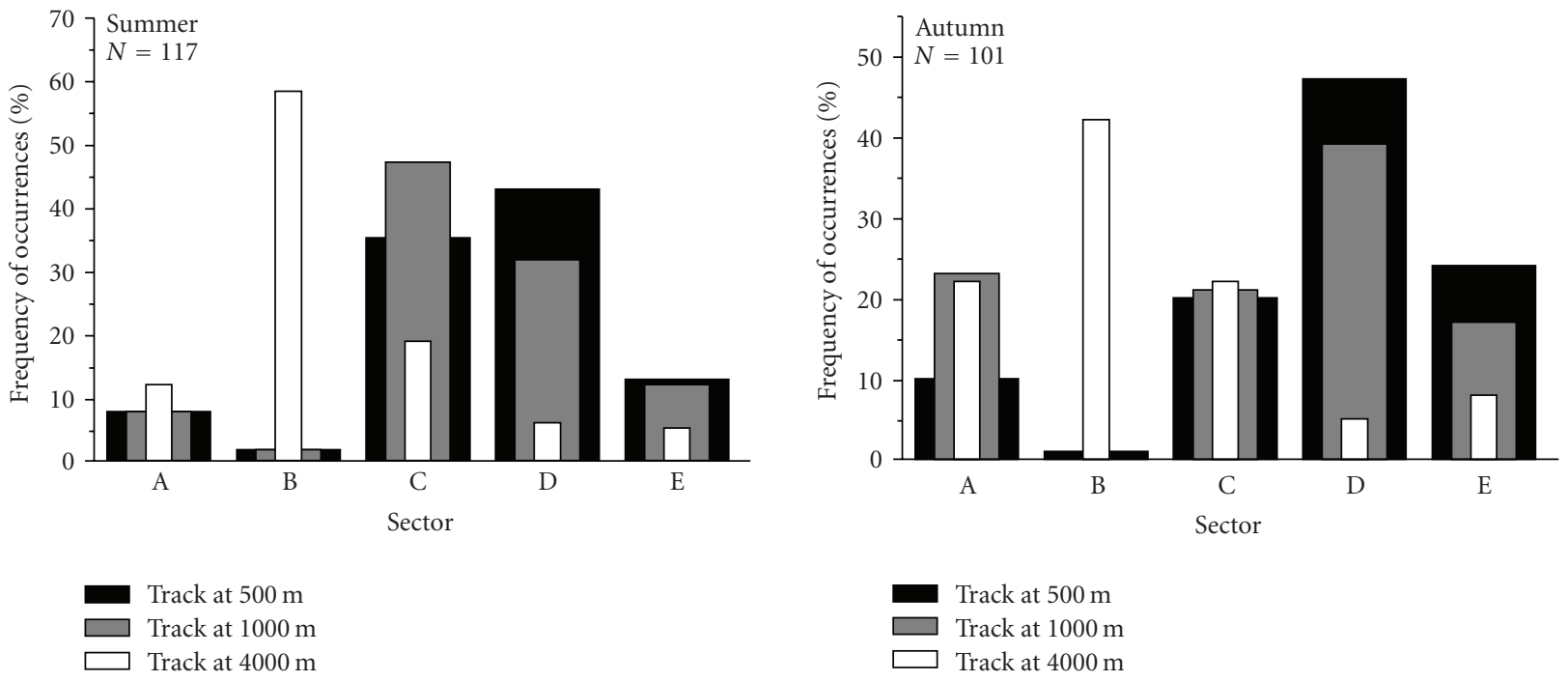

(c)

(d)

Figure 6: Seasonal frequency (\%) distribution of the air-mass trajectories at three atmospheric levels over GAA for the UI aerosol type. The number of data, $\mathrm{N}$, in each season is also given.

Central Europe. The lower $\mathrm{AOD}_{550}$ compared to Sector D could be a consequence of the control in emissions and air pollution in the countries of Western and Central Europe.

It is obvious that for the whole dataset the differences in the air-mass altitudes and in the number of trajectory occurrences do not affect the aerosol properties in the vertical. Nevertheless, larger differences are computed for the FM values rather than $\mathrm{AOD}_{550}$. These results are in agreement with those presented by Pace et al. [36] who prepared a similar sensitivity study changing the border of the sectors and the duration of the back-trajectories. They also found higher differences in $\alpha$-Ångström rather than AOD. The mean $\mathrm{AOD}_{550}$ and $\mathrm{FM}$ values computed in our analysis are in close agreement with the results obtained for Northern Greece by Amiridis et al. [30], who found higher AODs to correspond to eastern, local, and southern sectors and lower for the western. These also agree with the results conducted by Formenti et al. [39] at Mount Athos (North Greece) in June-September 1998. They found that the largest values of $\alpha$ correspond to air masses coming from Eastern Europe and former Soviet Union. Furthermore, Pace et al. [36] found that low values of $\alpha$-Ångström at Lampedusa were measured for air masses coming from North Africa, while air masses originating from Europe showed progressively increasing values.

Table 2 summarizes the mean and standard deviations of $\mathrm{AOD}_{550}$ and FM values proportionally to the Sector and airmass altitude for the UI type. Due to the limited range of FM values corresponding to the UI type $(0.8-1.0)$ the differences 

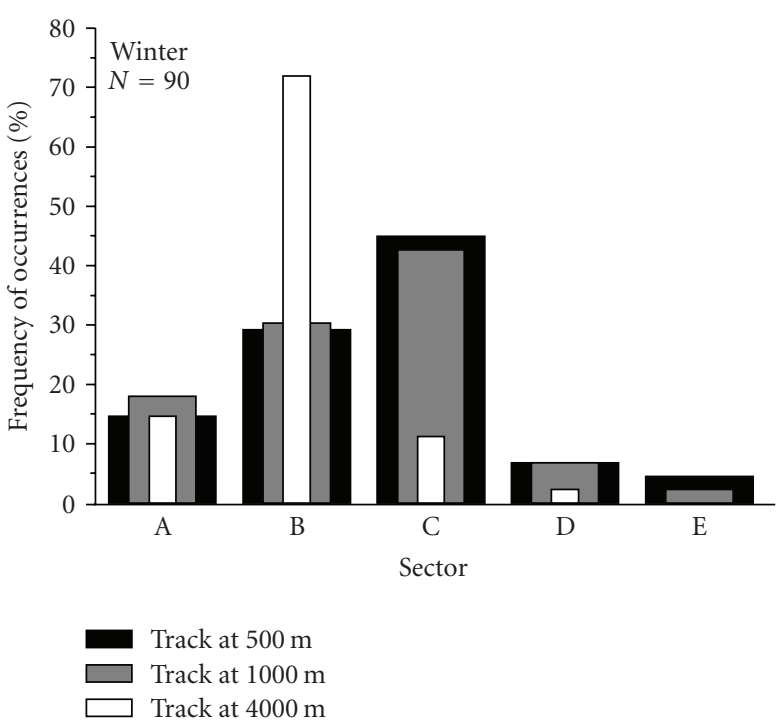

(a)

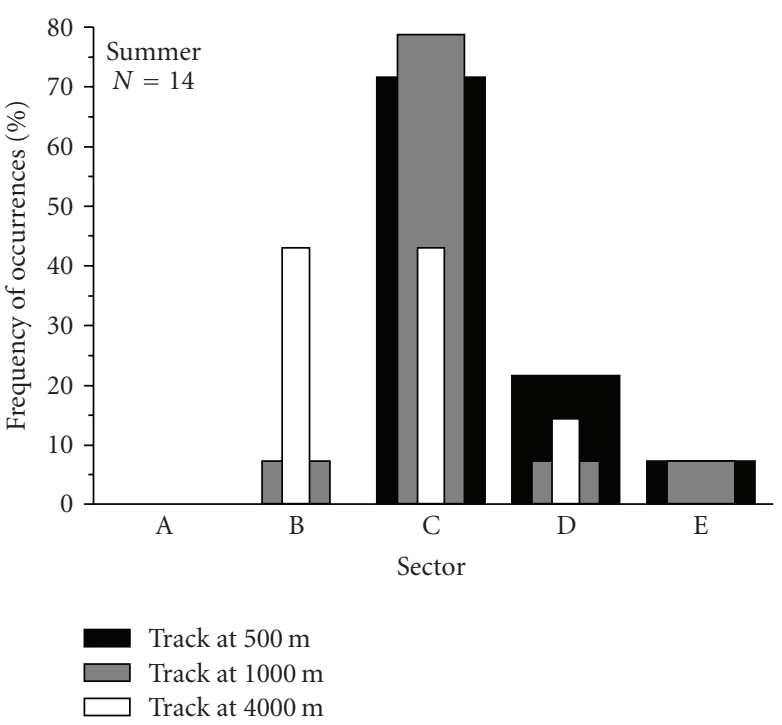

(c)

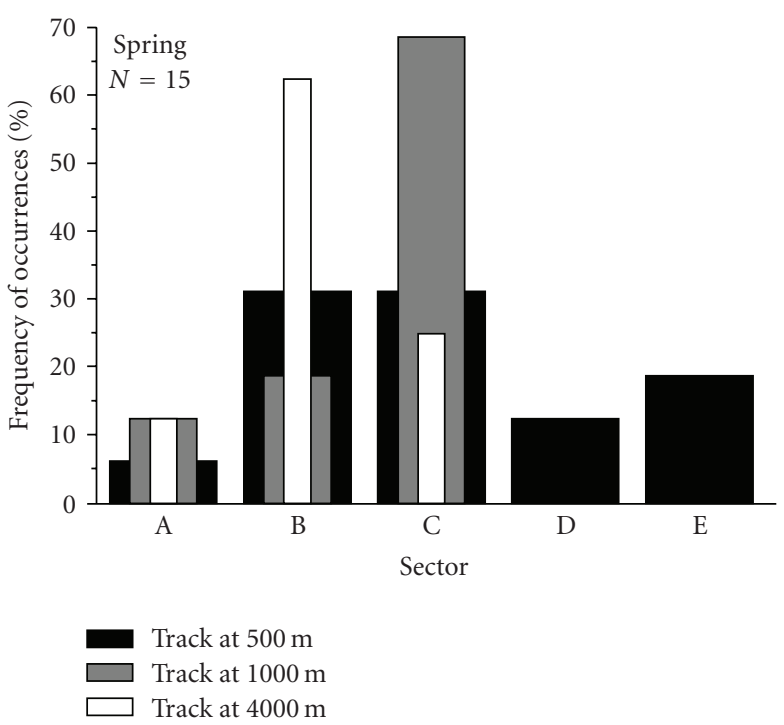

(b)

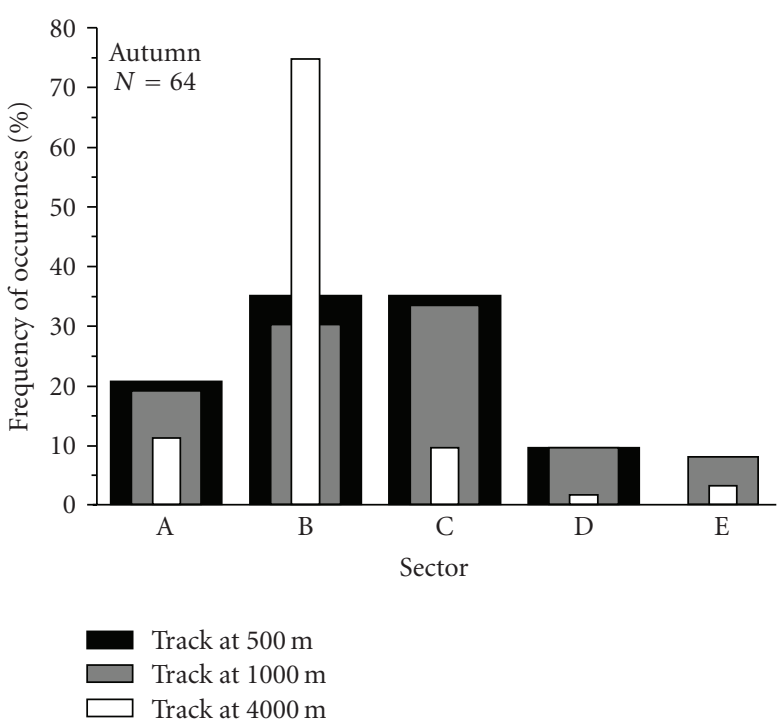

(d)

Figure 7: Same as in Figure 6, but for the CM aerosol type.

in this parameter are negligible. Also, very high $\mathrm{AOD}_{550}$ values, varying from 0.42 to 0.48 , are computed almost independently from the sector and the air-mass altitude. As previously mentioned, the UI type is favored by air masses within the boundary layer and the aerosol properties can more safely be studied for trajectories at 500 and $1000 \mathrm{~m}$. Therefore, the higher $\mathrm{AOD}_{550}$ is associated with air masses from the Sectors D and E, further confirming the transport or the accumulation of pollutants. The high mean $\mathrm{AOD}_{550}$ values corresponding to the Sector B (0.45) are referred to a limited number of data (3\%) and are attributed to three days when the Athens environment can be characterized as "pollution smog." The large standard deviations also confirm that these values are not representative for the whole dataset. $\mathrm{An}$ additional interesting finding is the highest mean $\mathrm{AOD}_{550}$ values ( 0.47 and 0.48$)$ corresponding to air masses at $4000 \mathrm{~m}$ from Sectors A and E. It was found that 18 out of 21 cases from the Sector E correspond to air masses from south directions (Libyan Sea) enriched with dust aerosols at the upper levels. Therefore, under such conditions, that is, heavy anthropogenic aerosols in the boundary layer associated with uplifted layer of Saharan dust enhance the aerosol load over Athens.

As regards the $\mathrm{CM}$ aerosol type, the lowest $\mathrm{AOD}_{550}$ $(\sim 0.13)$ corresponds to Sector B (Table 3$)$. Since the $\mathrm{AOD}_{550}$ range is limited $(0-0.2)$ for this type, no large variations between the sectors and air-mass altitudes in the $\mathrm{AOD}_{550}$ values are observed. Nevertheless, air masses probably carrying desert particles from Sector A or pollution from Sector D exhibit little higher $\mathrm{AOD}_{550}$ values $(0.15-0.16)$. 

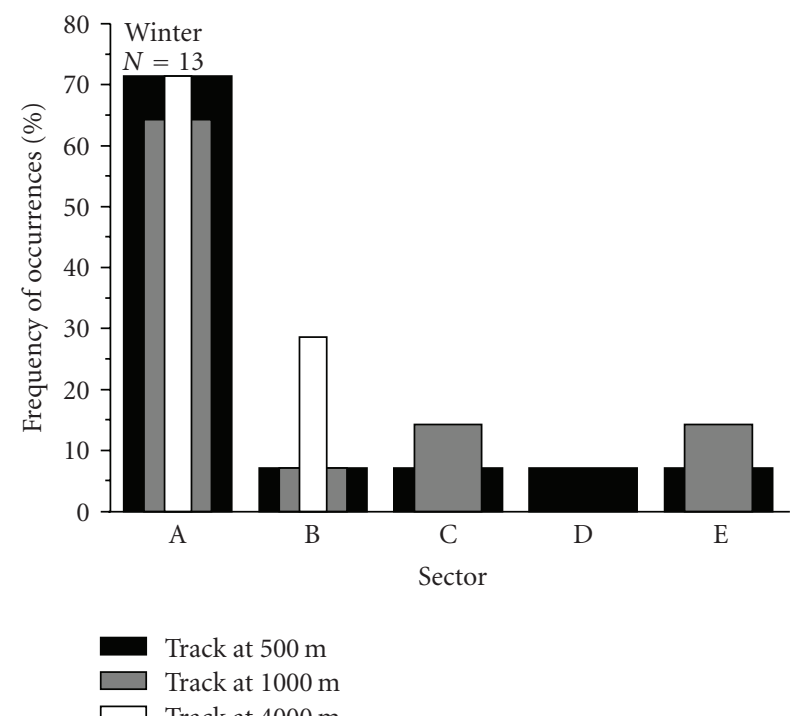
$\square$ Track at $4000 \mathrm{~m}$

(a)

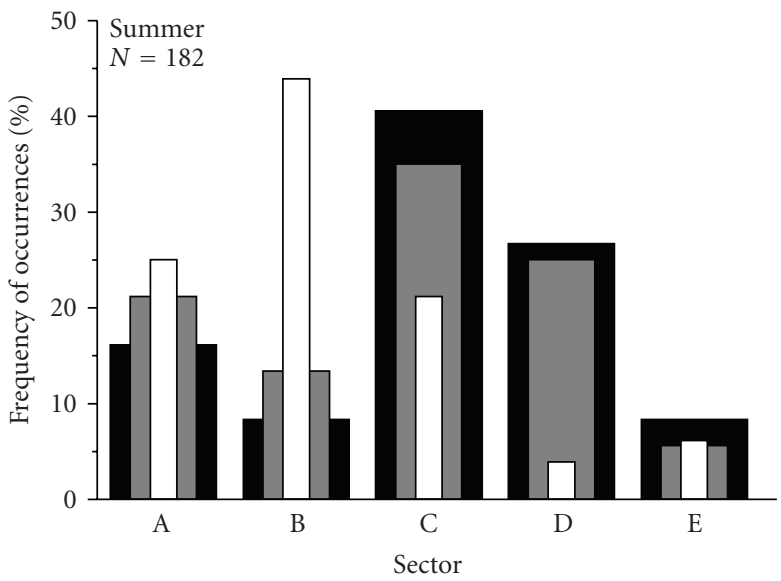
Track at $500 \mathrm{~m}$
Track at $1000 \mathrm{~m}$
$\square$ Track at $4000 \mathrm{~m}$
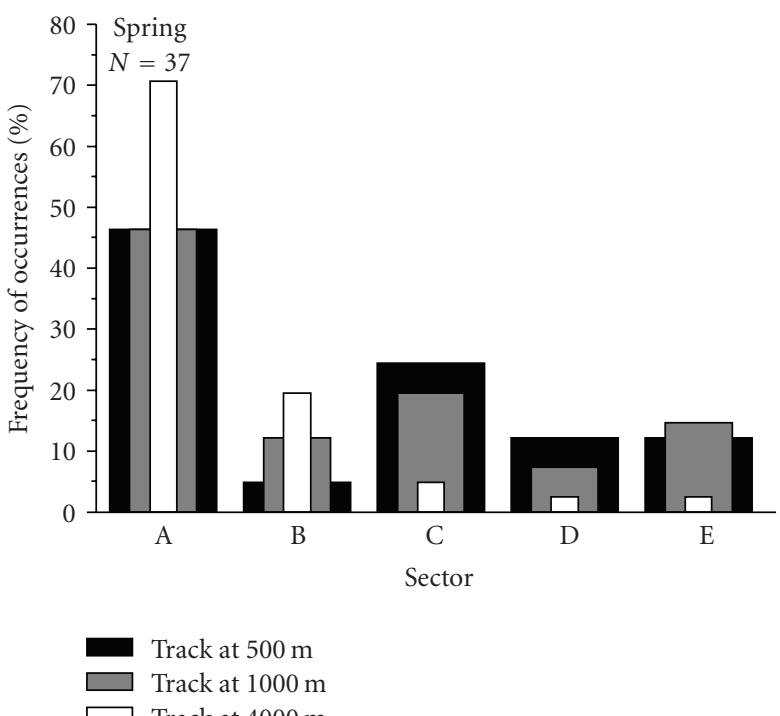
$\square$ Track at $4000 \mathrm{~m}$

(b)
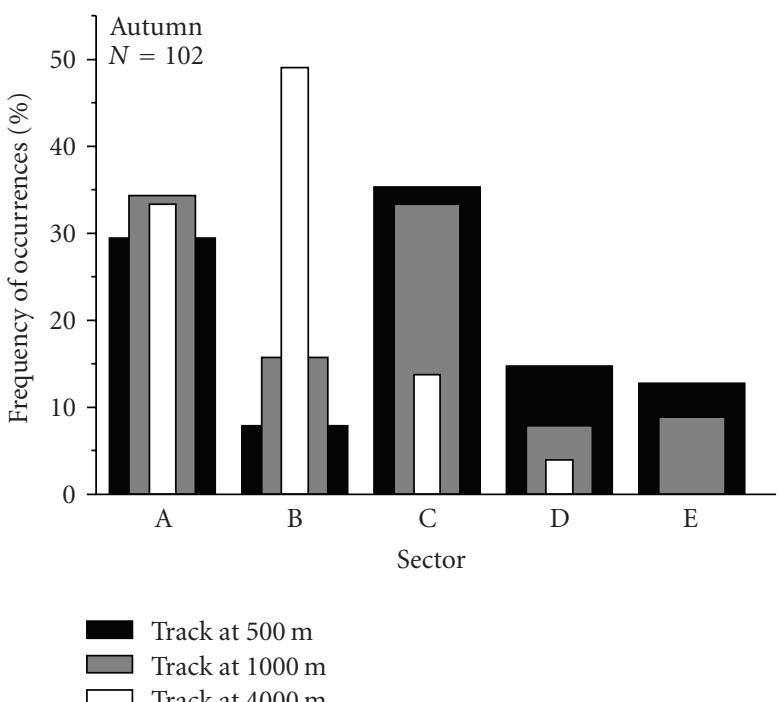

(c)

(d)

FIgure 8: Same as in Figure 6, but for the DD aerosol type.

On the other hand, higher variations are observed regarding the FM values. Therefore, the higher contribution of the coarse-mode particles (desert dust or sea spray) as well as the contribution of the fine-mode aerosols (local or transported pollution) to the total $\mathrm{AOD}_{550}$ is more intense for the Sectors A, B (0.46-0.51) and D, E (0.55-0.62), respectively.

As regards the DD type, it was established that this type can be divided into two groups: (a) desert-dust aerosols of Saharan origin and (b) coarse-mode particles (seaspray or soil dust) from northern directions. The $\mathrm{AOD}_{550}$ and FM values at the three altitudes presented in Table 4 further confirm the previous assumptions. An increase in $\mathrm{AOD}_{550}$ values (from 0.53 to 0.57 ) from Sector $\mathrm{A}$ is observed as the air-mass altitude increases; this suggests that the dust transport over GAA occurs mainly in the free troposphere. Inversely, lower $\mathrm{AOD}_{550}$ values (0.49 to 0.54 ) correspond to Sector D, exhibiting a decreasing trend with the air-mass altitude. As expected, the lowest $\mathrm{AOD}_{550}$ values (0.44) are associated with air masses from the Atlantic Ocean. Another interesting feature is the very high $\mathrm{AOD}_{550}$ value $(0.59 \pm 0.24)$, despite the limited number of cases (12), corresponding to air masses at $4000 \mathrm{~m}$ from Sector E. Additionally, even in cases when DD is the dominant aerosol type in the vertical, the local emissions and the anthropogenic aerosols associated with Sectors D and E increase the FM values, which are the lowest for air masses originating in Sector B. 

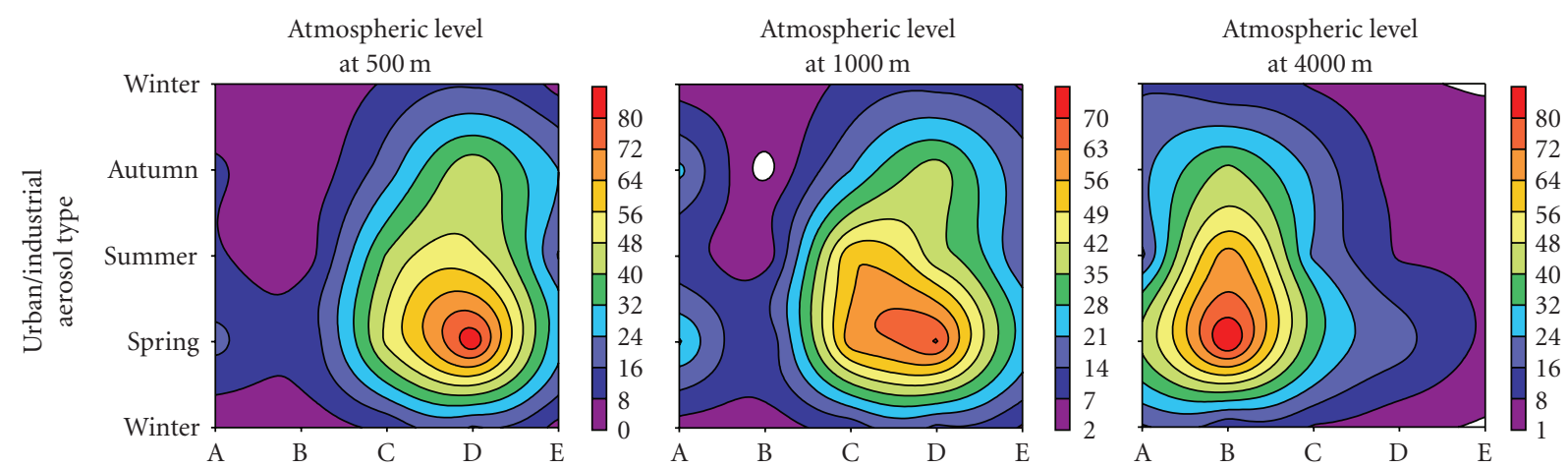

(a)
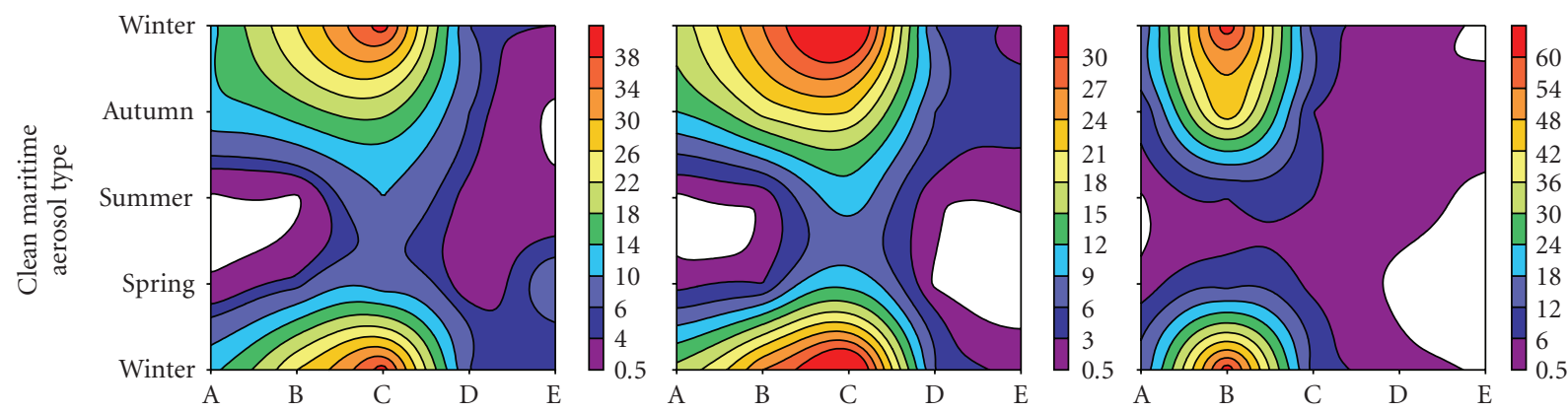

(b)
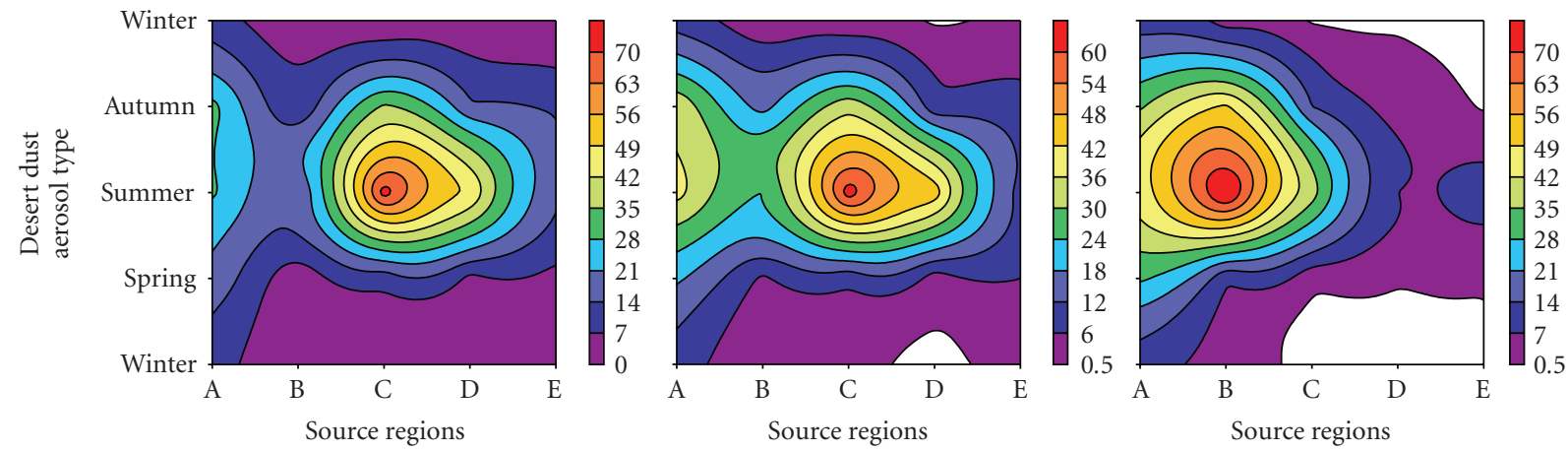

(c)

FIGURE 9: Contour plot of the seasonal frequency distribution of the air-mass trajectories at three atmospheric levels over GAA for all aerosol types. The white gaps correspond to lack of data.

\section{Conclusions}

Terra-MODIS aerosol products $\left(\mathrm{AOD}_{550}\right.$ and $\left.\mathrm{FM}\right)$ obtained over Athens, Greece, have been analyzed in order to provide information about the climatological characteristics of the aerosol optical properties. The data cover the period February 2000-December 2005. Based on $\mathrm{AOD}_{550}$ and $\mathrm{FM}$ values three main aerosol types corresponding to urban/industrial (UI) aerosols, clean maritime (CM) conditions, and coarsemode desert dust (DD) particles were discriminated. The investigation of the source regions, via 4-day air-mass backtrajectory analysis at three altitudes, showed that the UI type is favored by air masses within the boundary layer originating from Eastern Europe or due to local emissions. In contrast, the desert-dust conditions are associated with African air masses mainly at the upper atmospheric levels, while clean maritime conditions, although rare, are associated with fastmoving air masses from the Atlantic Ocean. In almost all cases, African aerosols display high values of $\mathrm{AOD}_{550}$ and low values of FM, typical of Saharan dust (mean values of $\mathrm{AOD}_{550}$ and $\mathrm{FM}$ are $\sim 0.39$ and $\sim 0.60$, resp.). Particles originating from Eastern Europe show relatively large average values of $A_{O D} D_{500}$ and FM (0.38 and 0.65$)$ respectively, while particles from North Atlantic show the lowest $\mathrm{AOD}_{550}$ values (0.34) and relatively small values of FM (0.60), which are consistent with those of maritime aerosols. However, the identification of the aerosol type and properties based on air-mass trajectories is a rather difficult thing due to fast changes in the aerosol vertical distribution, which is caused by air masses of different origins in the vertical column. Many variations in the observed patterns of the aerosol types were attributed to the transport origins and meteorological 
conditions. Overall, this may overemphasize the importance of the processes relative to chemistry, emissions source strengths, and local influences on the observed variability of the aerosol type and properties. The close agreement of our results with other studies and chemical transport models gives credit to the analysis used in order to identify the transport mechanisms of different aerosol types over Athens. Therefore, the present methodology seems to be sufficient in monitoring the long-range transport of aerosols and pollutants at different atmospheric levels and can also be applicable for air-quality studies. However, despite the consistency of the present results with those of chemical transport models, the long-range transport may not always be the most importance factor in determining the observed aerosol properties over Athens. Therefore, some open issues still exist. How does the strong seasonal variability in the aerosol sources, such as secondary organic aerosols or photochemical pollution, affect the variability in the observed aerosol types? How does the effectiveness of sulfate aerosol formation in cloud processing impact the results? How does the mass of aerosols transported along any given trajectory vary or weigh the importance of that trajectory in the overall analysis? The approach taken in this manuscript cannot really address such issues, which would require chemical transport modeling to understand.

\section{Acknowledgments}

The authors would like to thank the MODIS science data support team (past and present) for processing data via Giovanni website. The HYSPLIT scientific team for providing the back-trajectory plots is also gratefully acknowledged.

\section{References}

[1] J. Haywood and O. Boucher, "Estimates of the direct and indirect radiative forcing due to tropospheric aerosols: a review," Reviews of Geophysics, vol. 38, no. 4, pp. 513-543, 2000.

[2] IPCC, "Summary for policymakers," in Climate Change 2007: The Physical Science Basis. Contribution of Working Group I to the Fourth Assessment Report of the Intergovernmental Panel on Climate Change, S. Solomon, D. Qin, M. Manning, et al., Eds., Cambridge University Press, Cambridge, UK, 2007.

[3] M. D. King, Y. J. Kaufman, D. Tanré, and T. Nakajima, "Remote sensing of tropospheric aerosols from space: past, present, and future," Bulletin of the American Meteorological Society, vol. 80, no. 11, pp. 2229-2259, 1999.

[4] F. Barnaba and G. P. Gobbi, "Aerosol seasonal variability over the Mediterranean region and relative impact of maritime, continental and Saharan dust particles over the basin from MODIS data in the year 2001," Atmospheric Chemistry and Physics, vol. 4, no. 9-10, pp. 2367-2391, 2004.

[5] C. D. Papadimas, N. Hatzianastassiou, N. Mihalopoulos, X. Querol, and I. Vardavas, "Spatial and temporal variability in aerosol properties over the Mediterranean basin based on 6-year (2000-2006) MODIS data," Journal of Geophysical Research D, vol. 113, no. 11, Article ID D11205, 2008.

[6] C. Moulin, C. E. Lambert, U. Dayan, et al., "Satellite climatology of African dust transport in the Mediterranean atmosphere," Journal of Geophysical Research D, vol. 103, no. D11, pp. 13137-13144, 1998.

[7] D. Antoine and D. Nobileau, "Recent increase of Saharan dust transport over the Mediterranean Sea, as revealed from ocean color satellite (SeaWiFS) observations," Journal of Geophysical Research D, vol. 111, no. 12, Article ID D12214, 2006.

[8] A. M. Tafuro, F. Barnaba, F. De Tomasi, M. R. Perrone, and G. P. Gobbi, "Saharan dust particle properties over the central Mediterranean," Atmospheric Research, vol. 81, no. 1, pp. 6793, 2006.

[9] D. G. Kaskaoutis, H. D. Kambezidis, P. T. Nastos, and P. G. Kosmopoulos, "Study on an intense dust storm over Greece," Atmospheric Environment, vol. 42, no. 29, pp. 6884-6896, 2008.

[10] D. Meloni, A. di Sarra, F. Monteleone, G. Pace, S. Piacentino, and D. M. Sferlazzo, "Seasonal transport patterns of intense Saharan dust events at the Mediterranean island of Lampedusa," Atmospheric Research, vol. 88, no. 2, pp. 134-148, 2008.

[11] J. Lelieveld, H. Berresheim, S. Borrmann, et al., "Global air pollution crossroads over the Mediterranean," Science, vol. 298, no. 5594, pp. 794-799, 2002.

[12] A. Stohl, S. Eckhardt, C. Forster, P. James, and N. Spichtinger, "On the pathways and timescales of intercontinental air pollution transport," Journal of Geophysical Research, vol. 107, Article ID D4684, 2002.

[13] B. N. Duncan and I. Bey, "A modeling study of the export pathways of pollution from Europe: seasonal and interannual variations (1987-1997)," Journal of Geophysical Research D, vol. 109, no. 8, Article ID D08301, pp. 1-19, 2004.

[14] J. Feichter, E. Kjellström, H. Rodhe, F. Dentener, J. Lelieveld, and G.-J. Roelofs, "Simulation of the tropospheric sulfur cycle in a global climate model," Atmospheric Environment, vol. 30, no. 10-11, pp. 1693-1707, 1996.

[15] J. M. Prospero, "Mineral and sea salt aerosol concentration in various ocean regions," Journal of Geophysical Research, vol. 84, no. C2, pp. 725-731, 1979.

[16] J. Heintzenberg, D. C. Covert, and R. Van Dingenen, "Size distribution and chemical composition of marine aerosols: a compilation and review," Tellus, Series B, vol. 52, no. 4, pp. 1104-1122, 2000.

[17] D. G. Kaskaoutis, P. Kosmopoulos, H. D. Kambezidis, and P. T. Nastos, "Aerosol climatology and discrimination of different types over Athens, Greece, based on MODIS data," Atmospheric Environment, vol. 41, no. 34, pp. 7315-7329, 2007.

[18] P. G. Kosmopoulos, D. G. Kaskaoutis, P. T. Nastos, and H. D. Kambezidis, "Seasonal variation of columnar aerosol optical properties over Athens, Greece, based on MODIS data," Remote Sensing of Environment, vol. 112, no. 5, pp. 2354-2366, 2008.

[19] Y. J. Kaufman and D. Tanrè, "Algorithm for remote sensing of tropospheric aerosol from MODIS," Algorithm Theoretical Basis Documents (ATBD-MOD-02), p. 85, 1998.

[20] R. C. Levy, L. A. Remer, S. Mattoo, E. F. Vermote, and Y. J. Kaufman, "Second-generation operational algorithm: retrieval of aerosol properties over land from inversion of moderate resolution imaging spectroradiometer spectral reflectance," Journal of Geophysical Research D, vol. 112, no. 13, Article ID D13211, 2007.

[21] D. A. Chu, Y. J. Kaufman, G. Zibordi, et al., "Global monitoring of air pollution over land from the Earth observing system-terra moderate resolution imaging spectroradiometer (MODIS)," Journal of Geophysical Research D, vol. 108, no. 21, article 4661, pp. ACH4.1-ACH4.18, 2003. 
[22] C. Ichoku, D. A. Chu, S. Mattoo, et al., "A spatio-temporal approach for global validation and analysis of MODIS aerosol products," Geophysical Research Letters, vol. 29, no. 12, pp. 1.1$1.14,2002$.

[23] D. A. Chu, Y. J. Kaufman, C. Ichoku, L. A. Remer, D. Tanré, and B. N. Holben, "Validation of MODIS aerosol optical depth retrieval over land," Geophysical Research Letters, vol. 29, no. 12, pp. 2.1-2.4, 2002.

[24] L. A. Remer, D. Tanré, Y. J. Kaufman, et al., "Validation of MODIS aerosol retrieval over ocean," Geophysical Research Letters, vol. 29, no. 12, pp. 3.1-3.4, 2002.

[25] R. C. Levy, L. A. Remer, D. Tanré, et al., "Evaluation of the moderate-resolution imaging spectroradiometer (MODIS) retrievals of dust aerosol over the ocean during PRIDE," Journal of Geophysical Research D, vol. 108, no. 19, pp. 10.110.13, 2003.

[26] R. C. Levy, L. A. Remer, and O. Dubovik, "Global aerosol optical properties and application to moderate resolution imaging spectroradiometer aerosol retrieval over land," Journal of Geophysical Research D, vol. 112, no. 13, Article ID D13210, 2007.

[27] L. A. Remer, Y. J. Kaufman, D. Tanré, et al., “The MODIS aerosol algorithm, products, and validation," Journal of the Atmospheric Sciences, vol. 62, no. 4, pp. 947-973, 2005.

[28] R. R. Draxler and G. D. Rolph, "HYSPLIT (Hybrid singleparticle Lagrangian Integrated Trajectory) model," NOAA Air Resources Laboratory, Silver, Spring, Md, USA, 2003, http://www.arl.noaa.gov/ready/hysplit4.html.

[29] A. Papayannis, D. Balis, V. Amiridis, et al., "Measurements of Saharan dust aerosols over the Eastern Mediterranean using elastic backscatter-Raman lidar, spectrophotometric and satellite observations in the frame of the EARLINET project," Atmospheric Chemistry and Physics, vol. 5, no. 8, pp. 20652079, 2005.

[30] V. Amiridis, D. S. Balis, S. Kazadzis, et al., "Four-year aerosol observations with a Raman lidar at Thessaloniki, Greece, in the framework of European Aerosol Research Lidar Network (EARLINET)," Journal of Geophysical Research D, vol. 110, no. 21, Article ID D21203, pp. 1-12, 2005.

[31] D. Meloni, A. di Sarra, G. Biavati, et al., "Seasonal behavior of Saharan dust events at the Mediterranean island of Lampedusa in the period 1999-2005," Atmospheric Environment, vol. 41, no. 14, pp. 3041-3056, 2007.

[32] Y. J. Kaufman, D. Tanré, and O. Boucher, "A satellite view of aerosols in the climate system," Nature, vol. 419, no. 6903, pp. 215-223, 2002.

[33] L. A. Remer and Y. J. Kaufman, "Dynamic aerosol model: urban/industrial aerosol," Journal of Geophysical Research D, vol. 103, no. D12, pp. 13859-13871, 1998.

[34] K. O. Ogunjobi, Z. He, and C. Simmer, "Spectral aerosol optical properties from AERONET Sun-photometric measurements over West Africa," Atmospheric Research, vol. 88, no. 2, pp. 89-107, 2008.

[35] A. Smirnov, B. N. Holben, O. Dubovik, R. Frouin, T. F. Eck, and I. Slutsker, "Maritime component in aerosol optical models derived from aerosol robotic network data," Journal of Geophysical Research D, vol. 108, no. 1, pp. AAC14.1AAC14.11, 2003.

[36] G. Pace, A. di Sarra, D. Meloni, S. Piacentino, and P. Chamard, "Aerosol optical properties at Lampedusa (Central Mediterranean). 1. Influence of transport and identification of different aerosol types," Atmospheric Chemistry and Physics, vol. 6, no. 3, pp. 697-713, 2006.
[37] K. K. Moorthy, S. S. Babu, and S. K. Satheesh, "Aerosol characteristics and radiative impacts over the Arabian Sea during the intermonsoon season: results from ARMEX field campaign," Journal of the Atmospheric Sciences, vol. 62, no. 1, pp. 192-206, 2005.

[38] K. K. Moorthy, S. S. Babu, and S. K. Satheesh, "Aerosol spectral optical depths over the Bay of Bengal: role of transport," Geophysical Research Letters, vol. 30, no. 5, pp. 53.1-53.4, 2003.

[39] P. Formenti, M. O. Andreae, T. W. Andreae, et al., "Aerosol optical properties and large-scale transport of air masses: observations at a coastal and a semiarid site in the Eastern Mediterranean during summer 1998," Journal of Geophysical Research D, vol. 106, no. D9, pp. 9807-9826, 2001.

[40] A. di Sarra, T. Di Iorio, M. Cacciani, G. Fiocco, and D. Fuà, "Saharan dust profiles measured by lidar at Lampedusa," Journal of Geophysical Research D, vol. 106, no. D10, pp. 10335-10348, 2001.

[41] N. Kalivitis, E. Gerasopoulos, M. Vrekoussis, et al., "Dust transport over the Eastern Mediterranean derived from total ozone mapping spectrometer, aerosol robotic network, and surface measurements," Journal of Geophysical Research D, vol. 112, no. 3, Article ID D03202, 2007.

[42] D. Melas, H. D. Kambezidis, J. L. Walmsley, et al., "Summary of meeting: NATO/CCMS pilot study workshop on air pollution transport and diffusion over coastal urban areas," Atmospheric Environment, vol. 29, no. 24, pp. 3713-3718, 1995.

[43] C. Zerefos, K. Ganev, K. Kourtidis, M. Tzortziou, A. Vasaras, and E. Syrakov, "On the origin of $\mathrm{SO}_{2}$ above Northern Greece," Geophysical Research Letters, vol. 27, no. 3, pp. 365-368, 2000.

[44] J. Sciare, H. Bardouki, C. Moulin, and N. Mihalopoulos, "Aerosol sources and their contribution to the chemical composition of aerosols in the Eastern Mediterranean Sea during summertime," Atmospheric Chemistry and Physics, vol. 3, pp. 291-302, 2003.

[45] P. Alpert, P. Kishcha, A. Shtivelman, S. O. Krichak, and J. H. Joseph, "Vertical distribution of Saharan dust based on 2.5year model predictions," Atmospheric Research, vol. 70, no. 2, pp. 109-130, 2004.

[46] D. S. Balis, V. Amiridis, C. Zerefos, et al., "Raman lidar and sunphotometric measurements of aerosol optical properties over Thessaloniki, Greece during a biomass burning episode," Atmospheric Environment, vol. 37, no. 32, pp. 4529-4538, 2003. 

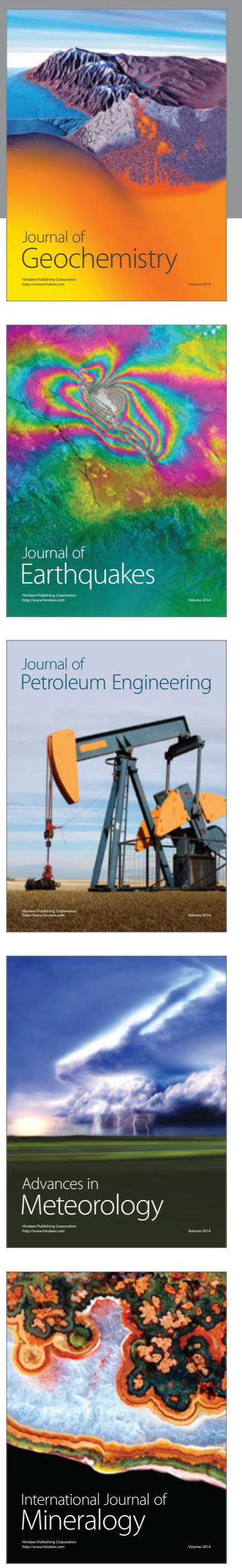
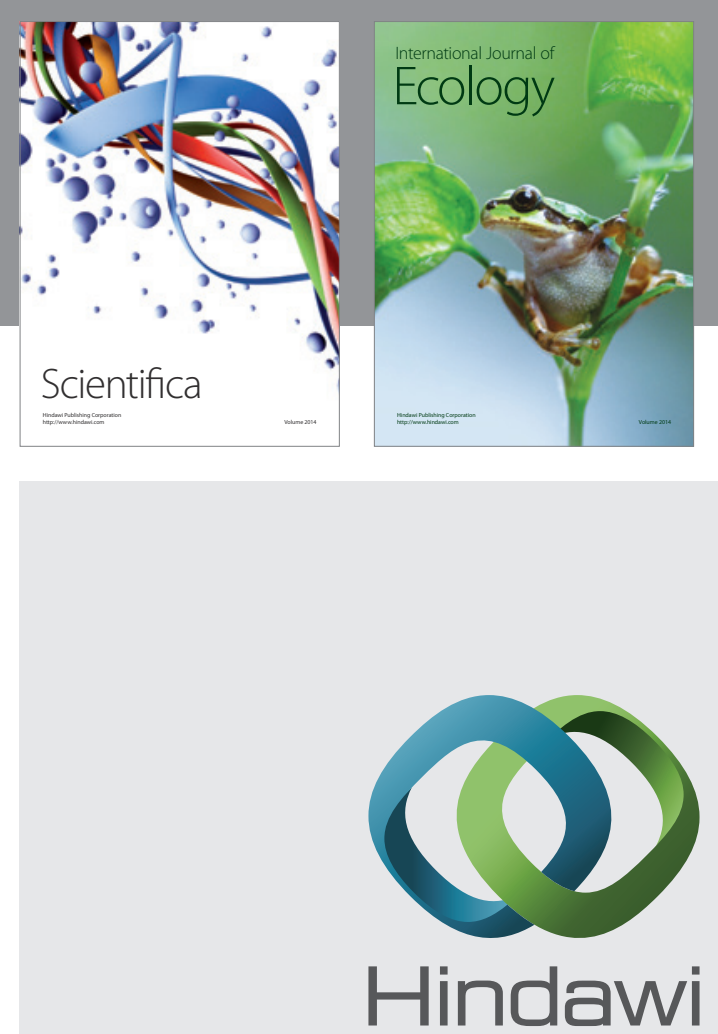

Submit your manuscripts at http://www.hindawi.com
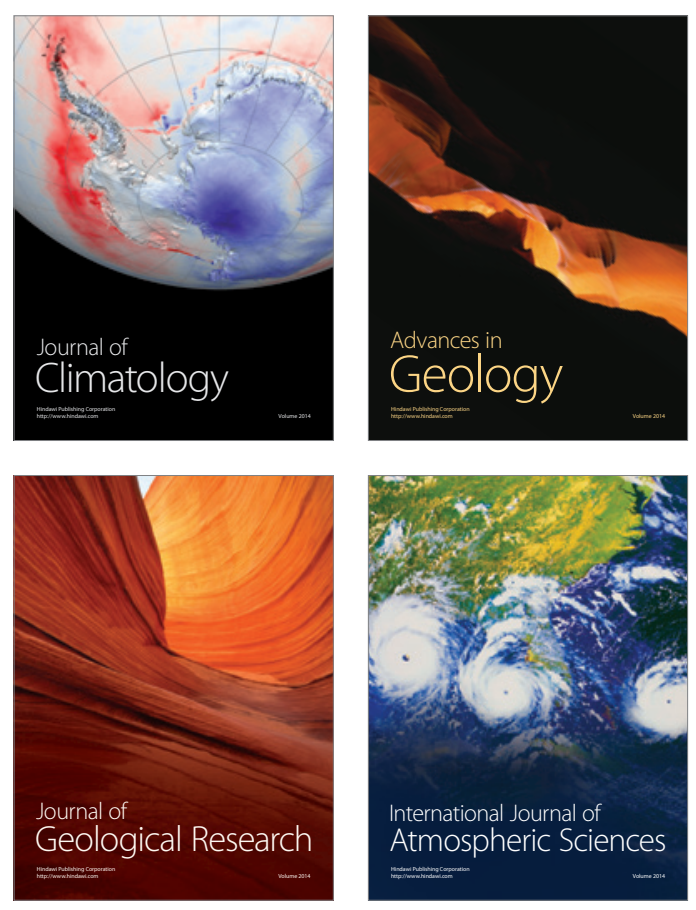
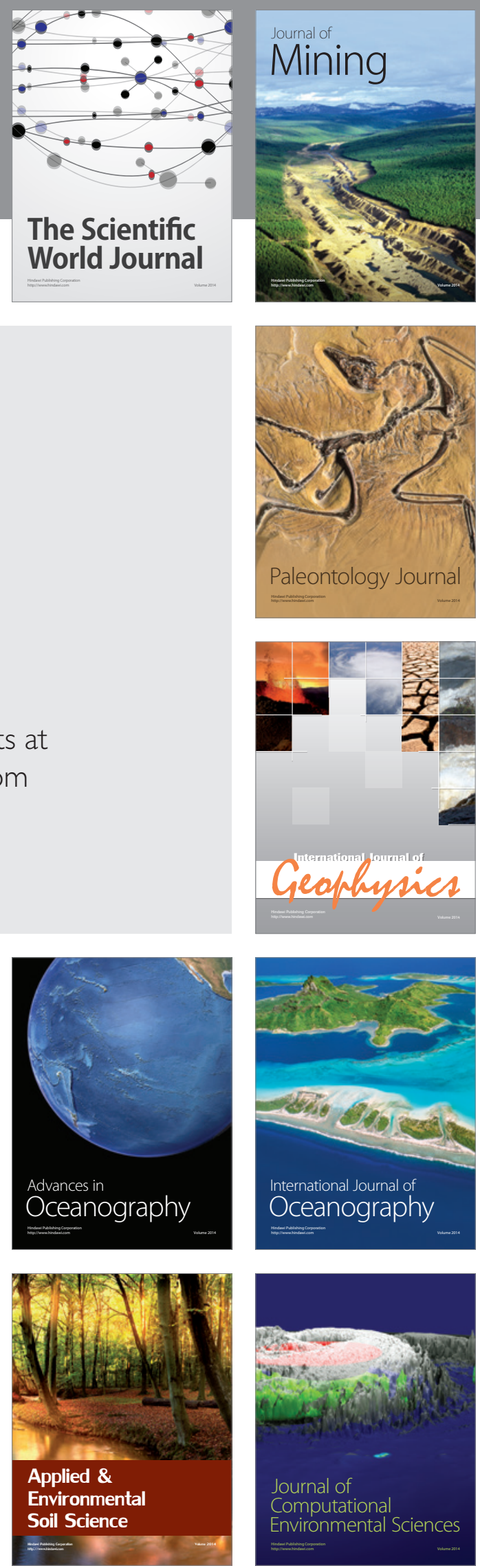